\title{
Use of high-intensity data to define large river management units: A case study on the lower Waikato River, New Zealand
}

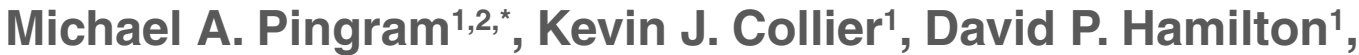 \\ Bruno O. David ${ }^{3}$ \& Brendan J. Hicks ${ }^{1}$
}

With 10 figures and 3 tables

\begin{abstract}
The importance of environmental heterogeneity in lotic ecosystems is well recognised in river management, and continues to underpin studies of hierarchical patch dynamics, geomorphology and landscape ecology. We evaluated how physical characteristics and water chemistry measurements at high spatiotemporal resolution define channel units of potential ecological importance along $134 \mathrm{~km}$ of the lower Waikato River in North Island, New Zealand. We used multivariate hierarchical clustering to classify river reaches in an a priori unstructured manner based on (i) high-frequency, along-river water quality measurements collected in four seasons and (ii) river channel morphology data resolved from aerial photos for 1-km long reaches. Patterns of channel character were shaped by the depth and lateral complexity of constituent river reaches, while water quality patterns were represented by differences in clarity, chlorophyll fluorescence and specific conductance driven by tributary inflows in the mid-section of the river and tidal cycles in the lower section. Management units defined by physical characteristics or water quality did not necessarily align with boundaries typically reflecting clinal processes (e.g. tidal influence) or geomorphic, network or anthropogenic discontinuities. The results highlight the dynamic spatial and temporal properties of large rivers and the need to define clear objectives when deriving spatial units for management and research. Given that actions and targets for physical channel and water quality management may differ, the spatial extent identified for each of these does not necessarily need to directly coincide, although both should be considered in decision making and experimental design.
\end{abstract}

Keywords: Biofish, River Channel Complexity Ratio (RCCR), tributaries, tidal cycle, discontinuities.

\section{Introduction}

Rivers are dynamic ecosystems, with longitudinal, lateral, vertical and temporal dimensions (Ward 1989), that offer an array of diverse habitats in time and space (Woodward \& Hildrew 2002). Longitudinal patterns in ecosystem function have been identified across several river types (Hadwen et al. 2010), supporting the view of rivers as continua where clinal gradients in resource availability regulate biological patterns (e.g. Vannote et al. 1980). In- puts from major tributaries (Kiffney et al. 2006), as well as anthropogenic discharges (Varol et al. 2011) and impoundments (Ward \& Stanford 1983), may disrupt continua and alter hydrogeomorphic, water quality and foodweb properties along the fluvial gradient. Alternatively, studies in eco-geomorphology have revealed hierarchical patterns of physical and biological associations across a range of spatial scales (Parsons \& Thoms 2007), leading to the concept of functional process zones where repeating combinations of hydrology and geology shape river-

\footnotetext{
Addresses of authors:

${ }^{1}$ Environmental Research Institute, University of Waikato, Private Bag 3105, Hamilton 3240, New Zealand.

${ }^{2}$ Department of Conservation, Private Bag 3072, Hamilton 3240, New Zealand.

${ }^{3}$ Waikato Regional Council, PO Box 4010, Hamilton, New Zealand.

*Corresponding author: michaelpingram@gmail.com
} 
ine habitats and processes (Thorp et al. 2006; 2008). Understanding factors that drive longitudinal patterns in the physical and biological features of rivers is of interest not only to ecologists (Power \& Dietrich 2002), but also to river managers seeking to implement actions that ameliorate human impacts.

Rivers are amongst the most regulated and altered ecosystems on Earth, with only $35 \%$ of large river systems remaining unfragmented by dams or unaffected by hydrological regulation for flood control, hydro-electricity generation, irrigation or navigation (Nilsson et al. 2005). Consequently, human development has led to changes in river function and character, increasing hydrological extremes, changing sediment transport, and altering channel formation and movement (Elosegi et al. 2010). In lowland rivers, lateral connections with floodplains and other waterbodies play vital roles in ecosystem function (Junk et al. 1989), but are often disconnected by flood control schemes. Lateral habitats, such as littoral zones, side arms, tributary confluences, oxbow lakes, lagoons and backwaters provide shelter from main channel flows and refugia for many aquatic organisms (Schiemer \& Hein 2007). In addition to current velocity and hydraulic retention, these habitats can differ from the main channel and each other in terms of nutrient processing rates, substrate composition, riparian input and shading, temperature, turbidity and the degree of riverine interaction (Schiemer \& Hein 2007; Thorp et al. 2008). The diversity, distribution, connectivity and scale of these lateral habitats are therefore important to ecological function, particularly in structurally complex parts of river systems (Schiemer \& Hein 2007; Thorp et al. 2008).

The chemical composition of water can reflect natural processes related to climate and geology, but today is often strongly influenced by anthropogenic disturbances from land use change and waste water discharges, which can have both localised and cumulative impacts (Eyre \& Pepperell 1999; Chang 2008). Seasonal flow patterns moderate water quality effects such that point source inputs dominate at base flows but become masked by wider catchment effects at high flows (Eyre \& Pepperell 1999). Moreover, water quality is also a strong regulator of spatial and temporal patterns in ecological function and biodiversity (Dolédec et al. 2011; Collier et al. 2012).

Determining the scales at which physical and chemical patterns can be resolved into spatial units of similar environmental character is important for the development of management plans intended to enhance biodiversity and ecological function (Thorp et al. 2006, 2008). The overall aims of the study were therefore to (i) test a quantitative approach for objectively characterising spatial pattern along a longitudinal river gradient punctuated by physicochemical and hydrogeomorphic changes, (ii) de- termine differences in patterns identified using channel character or water quality features, and (iii) investigate the temporal fidelity of identified spatial units in relation to seasonal patterns in water quality. We used the lower $134 \mathrm{~km}$ of the Waikato River in northern New Zealand as a case study to demonstrate the utility of high intensity water quality measurements and river channel morphology data from aerial photos for resolving environmental patterns along large river systems.

\section{Methods}

\section{Study area}

The Waikato River is $442 \mathrm{~km}$ long and drains a total catchment area of 14,443 $\mathrm{km}^{2}$, of the North Island, New Zealand (Brown 2010). It is a seventh-order river with mean annual discharge of c. $450 \mathrm{~m}^{3} / \mathrm{s}$ at its mouth, conforming to definitions of a large river presented in the literature (Vannote et al. 1980; Nilsson et al. 2005). The catchment has been significantly altered from its natural state by hydroelectric power generation and flood protection (Collier et al. 2010). The furthest downstream dam forms Lake Karapiro. This dam acts as an effective barrier to the natural movement of aquatic fauna upstream (Fig. 1a), and regulates flow which can lead to hydro-peaking effects for several kilometres downstream (Fig. 1b). Our study was conducted downstream of this dam, on the lower river, where the channel is low-gradient, falling $22 \mathrm{~m}$ over c. $150 \mathrm{~km}$ to the sea (Collier et al. 2010). Land use in the catchment is predominantly pastoral $(74 \%$, as opposed to $6 \%$ native forest), and the river system is highly responsive to rainfall, with large flood flows after heavy rain, usually in winter and spring (Brown 2010; Collier et al. 2010). Although unimpeded by dams, $47 \%$ $\left(172 \mathrm{~km}^{2}\right)$ of the original floodplain is now disconnected from the lower river by $242 \mathrm{~km}$ of stopbanks, 269 floodgates and 69 pump stations (Mulholland 2010; Speirs et al. 2010). The lower river is fed by several major tributaries, including some derived from floodplain wetlands and lakes. The largest and most significant tributary is the Waipa River, which joins the main stem at Ngaruawahia (Fig. 1a). It augments mean river flow by c. $25 \%$ and can be responsible for flow and flood pulses that occur downstream (Brown 2010) (Fig. 1c). River levels in the lower reaches also respond to tidal cycles, particularly during periods of lower fluvial flows (Fig. 1d).

\section{Physical complexity}

Physical complexity was determined for 1-km long reaches using ArcGIS Version 10. River shoreline was digitised from recent aerial photos (Waikato Regional 

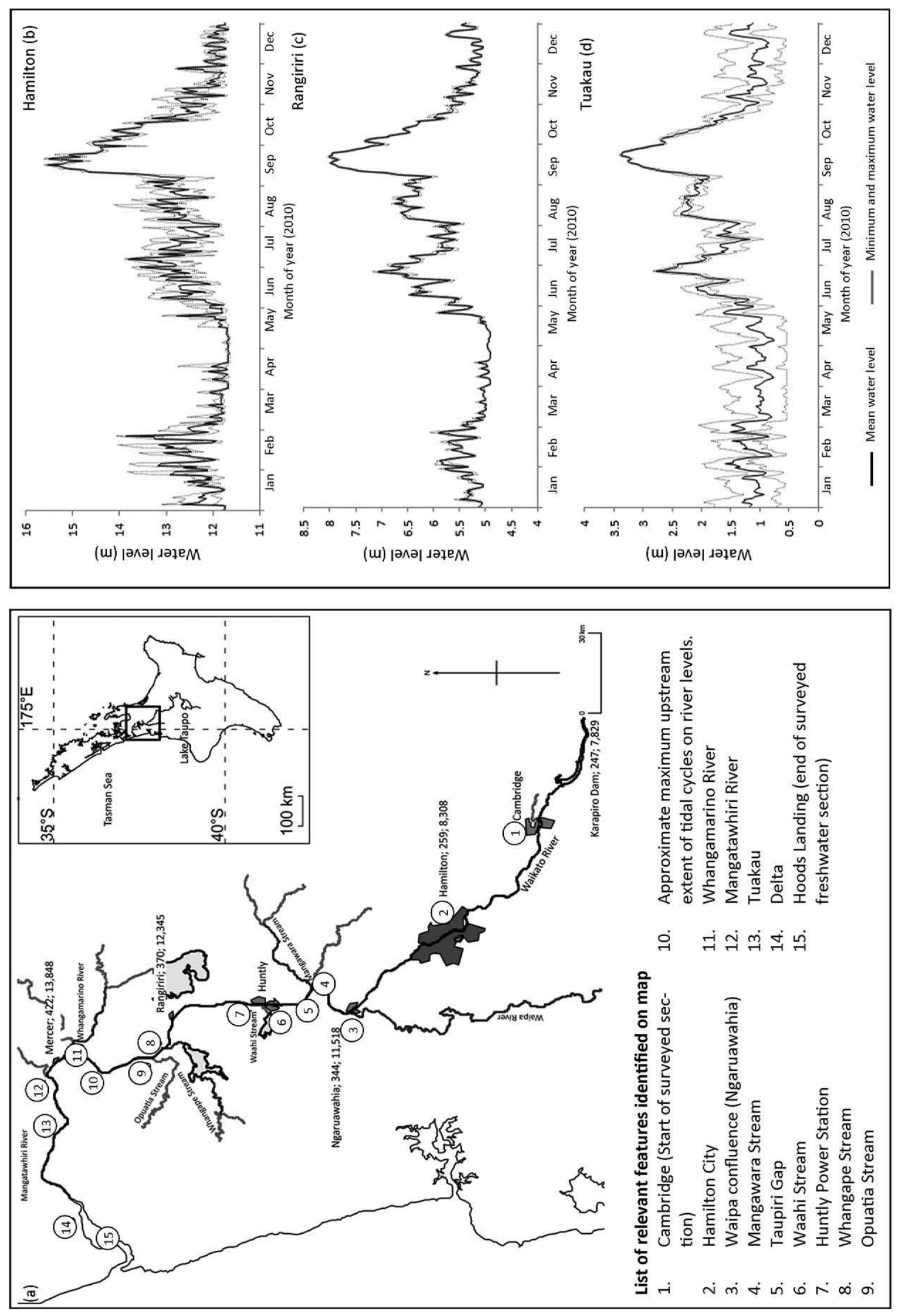

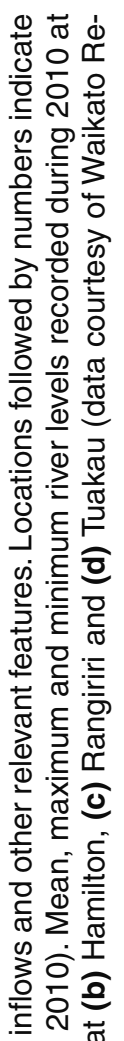

त 5

ब

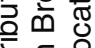

흐을 을

ब

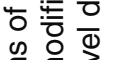

ट छे छ

䓞

ब

कै 을

종

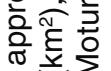

용요

词弯

$\subseteq \Phi \frac{\pi}{d}$

市

웡

荬 के

बे

으 잏

这

to

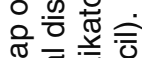

$\sum^{\pi} \frac{\pi}{2} \sum^{\frac{\pi}{5}}$

드 ర్ర

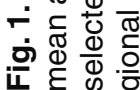


Council, Hamilton, New Zealand), and GIS tools were then used to create a centreline from which perpendicular dividing lines could be located to delineate $1 \mathrm{~km}$ reaches (polygons). Mean river width and channel shoreline length (indicative of shoreline complexity) were measured directly for each $1-\mathrm{km}$ polygon. The River Channel Complexity Ratio (RCCR) was calculated to reflect lateral complexity within the riverscape. RCCR is the ratio of total shoreline length of a polygon (including side arms and islands) to that of the main channel shoreline length (O'Neill \& Thorp 2011). The percentage of aquatic channel area for each reach was calculated by taking the total polygon area minus the area of the lateral features, such as islands and dividing it by the total polygon area expressed as percentage open water. Depth in the navigable channel (m) was measured by an echo sounder attached to the boat used conduct the water quality survey, as described below.

\section{Water quality survey}

Physicochemical measurements were taken during summer, autumn, winter and spring 2010. Data were collected using a Biofish underwater sensor array (ADM-Elektronik, Germany) towed by boat to collect real time, high frequency data on water quality (McBride et al. 2008). Surveys were restricted to water that could be safely navigated by boat (e.g. excluding rapids and sand bars), and therefore the upstream starting point was $7 \mathrm{~km}$ downstream of Karapiro dam at Cambridge (Fig. 1a). Surveys finished at the downstream extent of the delta islands, leading to a total surveyed distance of c. $137 \mathrm{~km}(144 \mathrm{~km}$ from Karapiro dam), although the last $3 \mathrm{~km}$ were excluded from analyses due to salt water intrusion. Surveys were completed over three consecutive days, apart from the spring survey when an equipment failure required spatially overlapping surveys on two separate two-day surveys (Cambridge to Huntly and Ngaruawahia to Hoods Landing; Fig. 1a).

Measurements of water clarity (per cent light transmittance), chlorophyll fluorescence (measured as relative fluorescence units), water temperature $\left({ }^{\circ} \mathrm{C}\right)$ and specific conductivity $(\mu \mathrm{S} / \mathrm{cm})$ were taken at a depth of c. $0.5 \mathrm{~m}$ using the Biofish. These measurements, and bed depth, were linked to a GPS reference (Garmin GPSMAP 168 Sounding). Data were automatically recorded to a computer along with longitude and latitude from a global positioning system. During each survey the Biofish was towed at a speed of 7 to $15 \mathrm{~km} / \mathrm{h}$, depending on river conditions. On return to the laboratory every $100^{\text {th }}$ Biofish and echo sounder data point was extracted from the data file (i.e. 25 second interval), and summarised in ArcGIS for each $1-\mathrm{km}$ reach using the polygon delineation method de- scribed above. Although downstream distance between points depended on boat speed and direction, the number of points summarised in each $\mathrm{km}$ of river reach was in excess of 100. Additional measurements were taken at regular intervals using a conductivity-temperature-depth (CTD) profiler (SBE 19 plus Seabird Electronics), fitted with additional beam transmittance and fluorescence sensors. Measurements from similar depths were then used to calibrate and validate Biofish fluorescence and transmittance readings (McBride et al. 2008).

\section{Data analysis}

Statistical analyses were undertaken using Primer 6 with PERMANOVA extension (Version 1.0.3). Prior to use in PRIMER data were normalised and converted to a Euclidean distance matrix. To identify functionally similar river reaches along the length of the surveyed section of the lower river, CLUSTER analysis was undertaken using group average distance and a SIMPROF analysis was used to identify groups of river reaches with $99 \%$ similar structure. Groups which were separated by $<1$ Euclidean distance unit in the CLUSTER dendrogram were deemed to be very closely related and were collapsed into single groups. A one-way SIMPER analysis was then carried out using these groups, to ascertain the variables responsible for similarities within groups and dissimilarities between groups (cumulatively up to $100 \%$ ). The major Principal Components Ordination (PCO) axes which accounted for the most variation in the data were selected and plotted to visualise relationships between sites and particular variables, illustrated by vector plots constructed using Spearman correlation coefficients. PCO based on Euclidean distance matrices in PRIMER are equivalent to Principal Components Analysis (PCA) used elsewhere (Anderson et al. 2008). Water quality and channel characteristics were analysed separately. For a more direct comparison with channel character analyses, an 'annual average' for each $1-\mathrm{km}$ reach was calculated for water quality variables from March, May, August and November surveys for reaches above the Waipa confluence and March, May, August and December surveys for reaches below. For seasonal analyses of water quality patterns the two surveys conducted during spring 2010 were also analysed separately due to notable changes in underlying flow conditions during the time between surveys (approximately four weeks). 


\section{Results}

\section{Physical complexity}

The surveyed section of the lower Waikato River was deepest above, and shallowest below the Waipa River confluence at Ngaruawahia (Fig. 2a), indicative of the marked shift in catchment geomorphology from a section dominated by ignimbrite walls and steep littoral zones to a sandier bottom and more open river channel, especially downstream of Huntly (Fig. 2a). This was particularly evident immediately above the Whangamarino River confluence and in the delta where the channel was often $<1 \mathrm{~m}$ deep and sand bars were common (Fig. 2a). Water depth in some tidally influenced reaches was greater than in some fluvial reaches downstream of the Waipa River. Mean channel width was generally lower above the Waipa, notably in the most upstream part of the survey between Cambridge and Hamilton, where the river can be narrow $(<10 \mathrm{~m})$ and deep $(>5 \mathrm{~m})$ (Fig. 2a, b). River width began to increase steadily below the Waipa confluence, with the widest reaches generally occurring downstream of the Mangatawhiri River confluence and slightly further downstream in the delta section, where average channel width was $>1.5 \mathrm{~km}$ (Fig. 2b). RCCR ratios and mean channel shoreline length ranged from 1.00-6.36 and $2.00-2.63$, respectively, and increased markedly downstream of the geomorphic constriction known as the
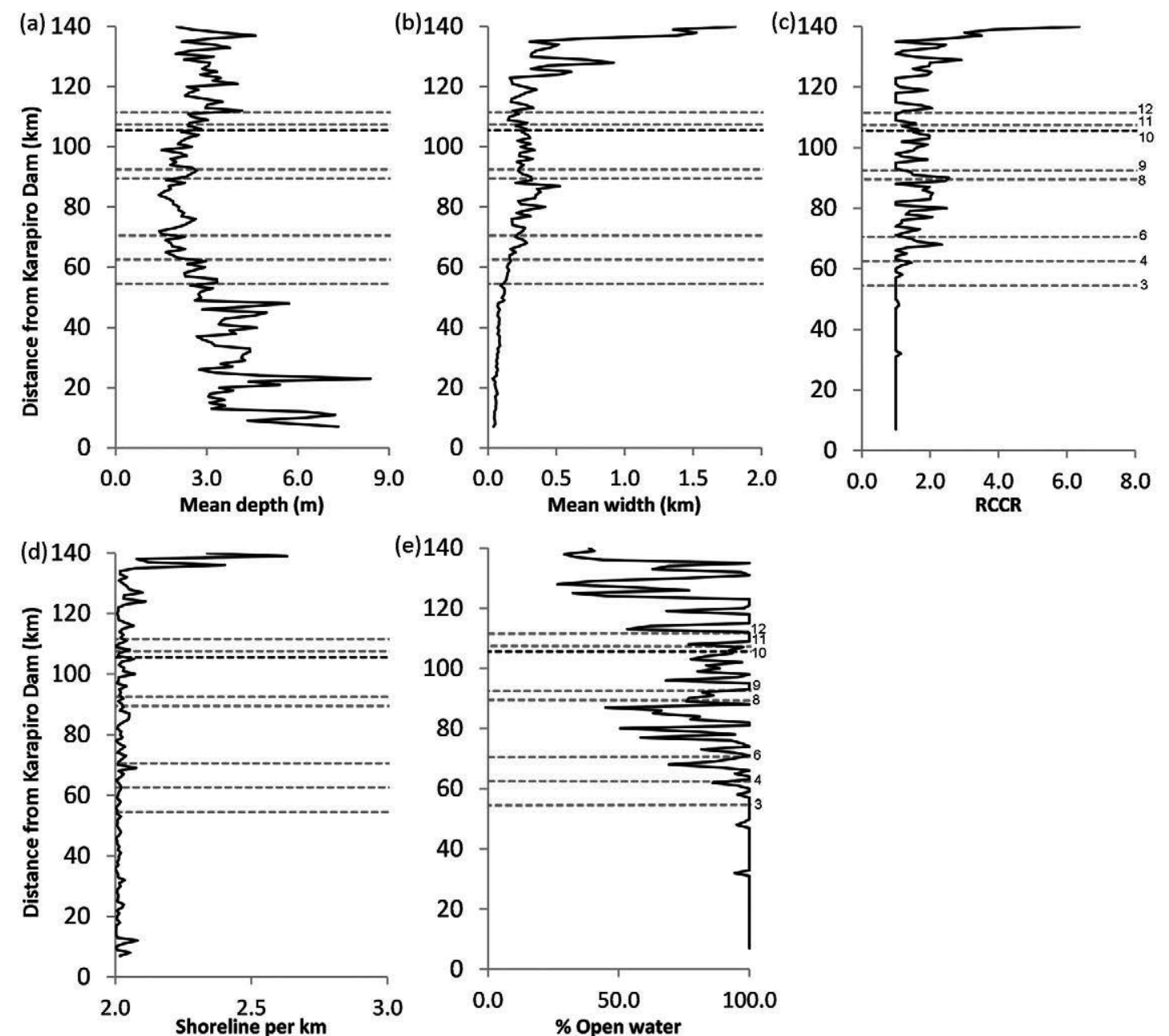

Fig. 2. Physical parameters summarised for each river kilometre measured from Karapiro dam. (a) Mean depth measured using a boat mounted transducer, (b) mean width, (c) River channel complexity ratio (RCCR), (d) channel shoreline per km and (e) percentage open water (b-e calculated using ArcGIS based on 1-km long polygons). Dashed lines represent locations of major tributaries to the lower Waikato River, and the approximate maximum upstream effect of tidal cycles on river levels. Numbers relate to locations listed in Fig. 1 a. 
Table 1. Mean ( \pm 1 SD) physical river characteristics for clusters identified using SIMPROF routines (see Figs. 3 \& 4). Superscripts denote percentage contribution to group structure $1,1-10 \% ; 2,11-20 \% ; 3,21-30 \%$ and so on.

\begin{tabular}{|llclcccc}
\hline $\begin{array}{l}\text { Reach type } \\
\text { (Cluster) }\end{array}$ & Description & $\mathbf{n}$ & $\begin{array}{l}\text { Mean depth } \\
(\mathbf{m})\end{array}$ & $\begin{array}{l}\text { Mean width } \\
(\mathbf{m})\end{array}$ & \multicolumn{2}{l}{ RCCR } & \multicolumn{2}{l}{$\begin{array}{l}\text { Shoreline per } \\
\text { km }\end{array}$} & $\begin{array}{l}\text { \% open } \\
\text { water }\end{array}$ \\
\hline P1 & Narrow and deep, low lateral complexity & 8 & $6.6(1.0)^{9}$ & $48.6(11.6)^{1}$ & $1.0(0.0)^{1}$ & $2.03(0.02)^{2}$ & $99(2)^{1}$ \\
\hline P2 & $\begin{array}{l}\text { Narrower and deeper than average, low } \\
\text { lateral complexity }\end{array}$ & 51 & $3.5(0.7)^{9}$ & $92.5(38.1)^{1}$ & $1.0(0.0)^{1}$ & $2.01(0.01)^{1}$ & $100(1)^{1}$ \\
\hline P3 & $\begin{array}{l}\text { Average width, but shallower than } \\
\text { average, low lateral complexity }\end{array}$ & 33 & $2.2(0.3)^{4}$ & $216.5(50.1)^{2}$ & $1.1(0.1)^{2}$ & $2.02(0.02)^{3}$ & $98(3)^{1}$ \\
\hline P4 & $\begin{array}{l}\text { Average width, shallower than average, } \\
\text { islands and/or side arms present }\end{array}$ & 24 & $2.2(0.5)^{3}$ & $294.7(48.4)^{1}$ & $1.8(0.3)^{4}$ & $2.03(0.02)^{2}$ & $79(8)^{3}$ \\
\hline P5 & $\begin{array}{l}\text { Above average width, islands and side } \\
\text { arms common }\end{array}$ & 10 & $2.8(0.6)^{3}$ & $412.8(93.2)^{2}$ & $2.1(0.2)^{2}$ & $2.04(0.04)^{4}$ & $57(9)^{3}$ \\
\hline P6 & $\begin{array}{l}\text { Wide, lateral features abundant } \\
\text { P7 }\end{array}$ & 5 & $3.4(0.9)^{2}$ & $1027.6(404.3)^{6}$ & $2.7(0.7)^{3}$ & $2.06(0.04)^{1}$ & $33(5)^{1}$ \\
\hline Wide, lateral features very abundant, & 3 & $2.6(0.6)^{1}$ & $1287.3(557.4)^{3}$ & $4.2(2.0)^{5}$ & $2.46(0.15)^{3}$ & $41(3)^{1}$ \\
\hline Total & shallower than P6 & 134 & $3.1(1.2)$ & $242.2(270.7)$ & $1.4(0.7)$ & $2.03(0.1)$ & $89(0.2)$ \\
\hline
\end{tabular}

Taupiri Gap (location 5 in Fig. 1a) upstream of Huntly (Fig. 2c, d). These morphological metrics highlight the increase in embayments, backwaters, side arms and islands, and a decreasing proportion of open water across the channel width (Fig. 2e), particularly in the delta region of the river. Interestingly, the RCCR ratio generally decreased in river reaches immediately below major tributary junctions.

CLUSTER and SIMPROF analyses resulted in characterisation of river reaches into seven significant groups or types of reach based on the physical variables measured for the surveyed section of the lower river. The characteristics of each cluster group are summarised in Table 1. The most common group (P2) accounted for c. $40 \%$ of river reaches in the surveyed river length, and was the dominant reach type in the first $60 \mathrm{~km}$ of the lower river. The first and second axes of the PCO explained $87.5 \%$ of the variability in the data (Fig. 3). Spearman correlation coefficients indicated that $\mathrm{P} 1$ and $\mathrm{P} 2$ reaches differed from the others primarily due to greater river depth (Fig. 3 ). Reaches to the left of the plot (progressively from P5 through P7) reflect increasing river width and higher RCCR ratios, are shallower and wider, and have a more complex channel with a longer shoreline length (embayments and backwaters) (Fig. 3). Cluster groups P2 and P3 formed a closely related 'family' which characterised $65 \%$ of reaches surveyed (Table 1, Fig. $4 a$ ). These two clusters, however, could be differentiated most strongly in terms of mean width and depth, with one being deeper (mean $4 \mathrm{~m}$ ) and narrower (mean $90 \mathrm{~m}$ ) and the other typically shallower (mean $2 \mathrm{~m}$ ) and wider (mean $200 \mathrm{~m}$ ). Deep (mean $7 \mathrm{~m}$ ), narrow reaches (mean $50 \mathrm{~m}$ ) only occurred above the Waipa confluence, mostly above Hamil- ton City (within c. $30 \mathrm{~km}$ downstream of Karapiro dam), and formed group P1 (Fig. 4b). Groups P4 to P7 represented increasing frequency and scale of lateral features (e.g. RCCR and shoreline length per $\mathrm{km}$ ) and also in-

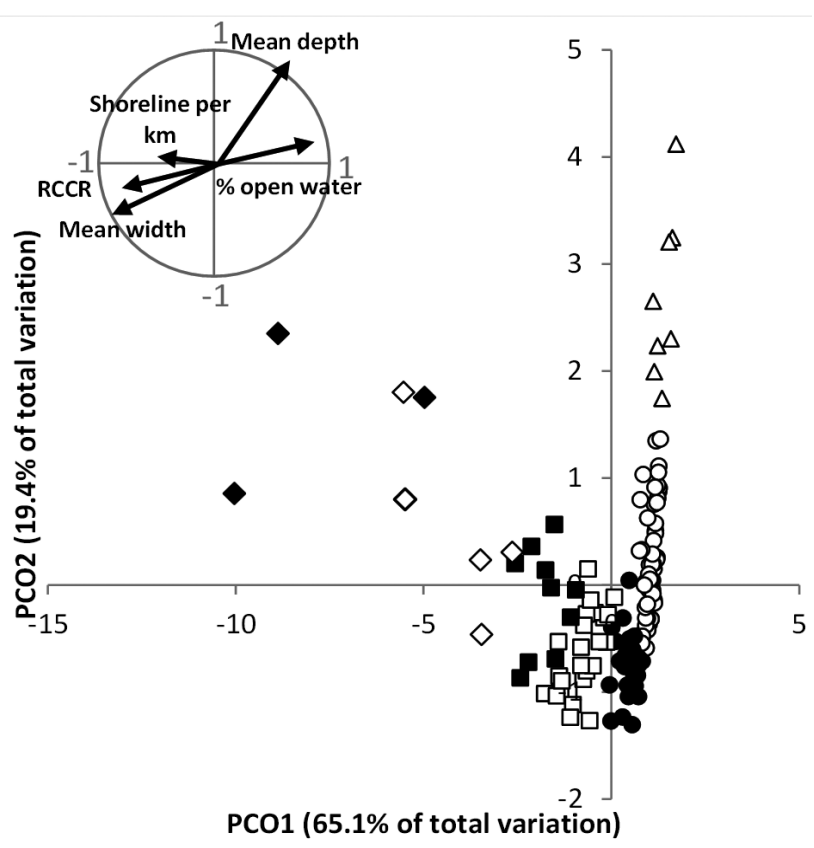

Key to reach types (Cluster): P1 $\triangle \triangle$ ), P2 (O), P3 (O), P4

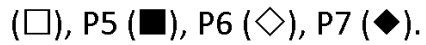

Fig. 3. Principal coordinates ordination of reach types identified using CLUSTER and SIMPROF analyses of physical variables. See Table 1 for summary of variables for each reach type. 
(a)

(b)
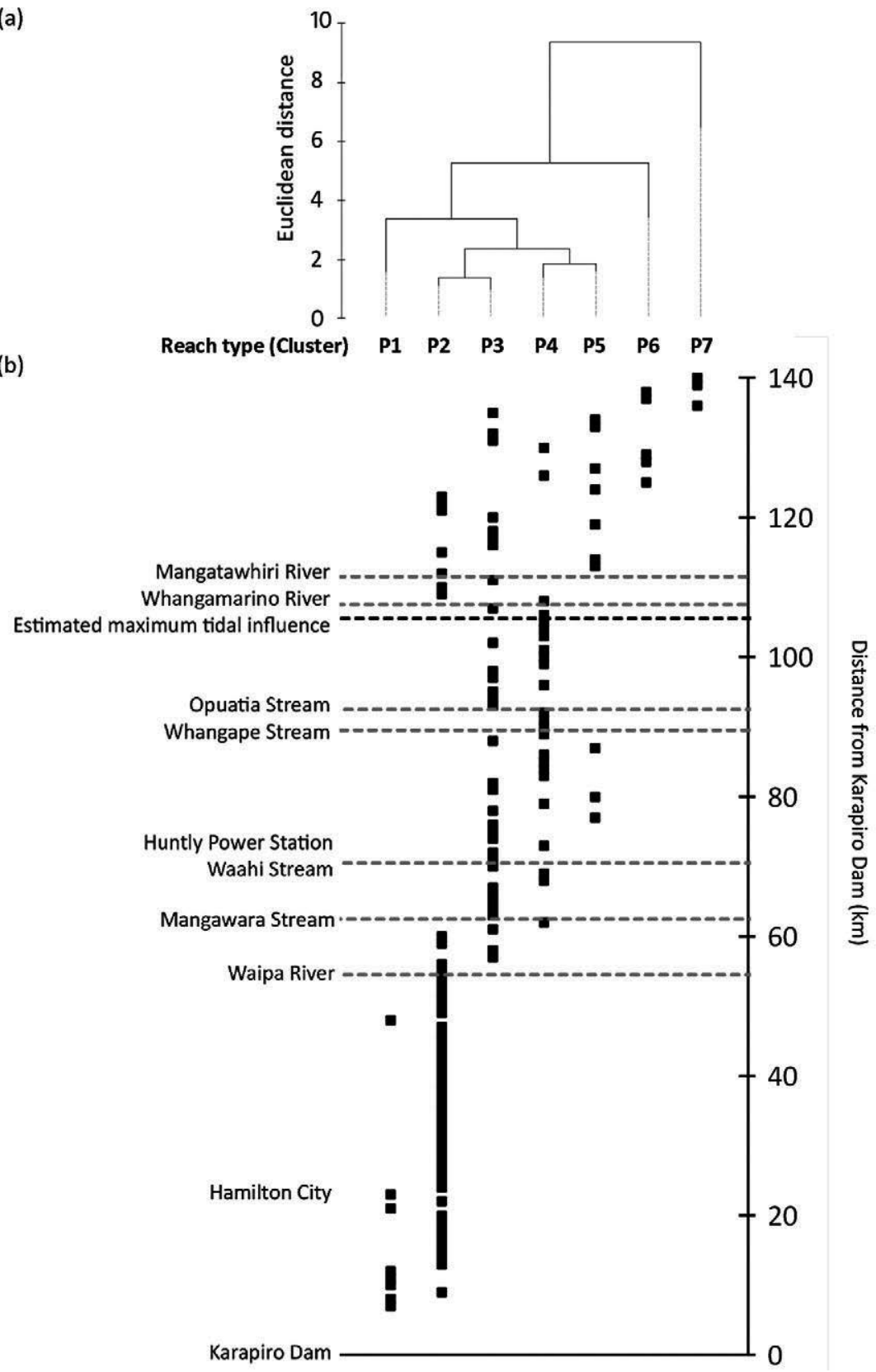

Fig. 4. (a) Dendrogram of relationships between reach types and (b) spatial arrangement of physical reach types along surveyed section of the lower Waikato River. See Fig. 4 and Table 1 for characteristics of each reach type (P1-P7). Dotted lines represent locations of major tributaries to the lower Waikato River, and the approximate maximum upstream effect of tidal cycles on river levels.

creasing mean width, although mean depth did not follow a longitudinal pattern.

Only two groups were present above the Waipa confluence; 8 deep and narrow river reaches belonging to group $\mathrm{P} 1$, which was unique to this section of river, and the remaining 40 reaches belonging to group $\mathrm{P} 2$, often uninterrupted for tens of kilometres. P2 also occurred im- mediately downstream of the Waipa confluence, and occasionally further downstream within the tidal influence, usually in narrow and deep river sections (Fig. 4b). In SIMPER analyses these two groups were most strongly characterised $(>80 \%)$ by mean river depth, with both groups having mean depth $\geq 3.5 \mathrm{~m}$; Table 1). The analyses identified another five groups which only occurred below 


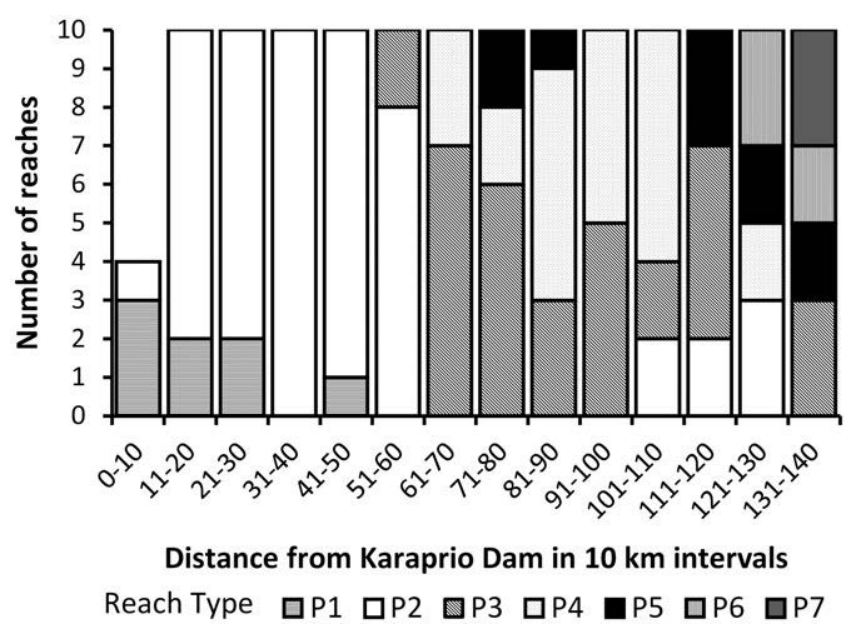

Fig. 5. Channel character cluster types summarised at $10 \mathrm{~km}$ intervals from Karapiro dam.

the Waipa confluence where the majority of river reaches were represented by two groups: $\mathrm{P} 3$ which was characterised by shallow river depths and low lateral complexity, and $\mathrm{P} 4$ which was also shallow but had a higher occurrence of lateral features (e.g. higher RCCR ratios and river shoreline length). Downstream of the Waipa confluence reach types tended to change more frequently, with fewer and shorter stretches of a single type. This variability increased downstream of the Mangatawhiri confluence (Fig. 4b), particularly below Tuakau (c.120 km downstream from Karapiro dam). Six different reach types occurred in the most downstream $20 \mathrm{~km}$ surveyed. Two of these, P6 and P7, were only located in the tidally-influenced section of the river and represented a total of eight $1 \mathrm{~km}$-long river reaches (Fig. 4b). The majority of P5 reach types also occurred in the tidally-influenced section of the lower river (Fig. 4b). SIMPER analyses indicated that these three groups were characterised by high RCCR ratios and mean width, with $\mathrm{P} 7$ also having high shoreline length (Table 1). When summarised at $10-\mathrm{km}$ intervals, the first $60 \mathrm{~km}$ of the lower river was dominated by P2 reach types (Fig. 5). P3 reach types then appeared and became the most common reach type between $61-89 \mathrm{~km}$, and also between 111-120 km from Karapiro dam. P4 reach types were most common between 81-90 and 101$110 \mathrm{~km}$, while P3 and P4 reach types were equally common 91-100 km from Karapiro dam. In river reaches further downstream than $121 \mathrm{~km}$ the number of different cluster types present in any $10-\mathrm{km}$ interval was at least four and no individual type could be said to dominate (Fig. 5).

\section{Water quality}

Measurements of water quality summarised using the same 1-km reaches as above, showed both spatial and seasonal patterns. Although somewhat variable down the length of the surveyed stretch of river, some general patterns in chlorophyll fluorescence were discernible. Fluorescence tended to decrease immediately below the Waipa River confluence and steadily increase once the river channel became tidally influenced, c. $115 \mathrm{~km}$ from Karapiro dam (depending on the season) (Fig. 6). Although similar patterns were observed in each month, an increase in fluorescence was less pronounced downstream of Mercer during winter (August; Fig. 6c). Depending on season, smaller fluctuations in fluorescence were also observed around specific locations, often coinciding with tributary junctions, notably the Mangawara, Whangape and Whangamarino confluences. Transmittance (water clarity) tended to decrease with increasing distance from Karapiro dam (Fig. 6). Localised decreases were also evident immediately downstream of tributaries, although there was often recovery further downstream. The Waipa River confluence was consistently associated with the largest changes in water clarity, most notably during high flows in winter when low transmittance persisted for the remainder of the survey downstream of the confluence (Fig. $6 c)$.

Water temperature was highest in summer (March) and lowest in winter (Fig. 6a, c). At low flows water temperature in the main channel generally decreased downstream of tributary confluences while the opposite was true at high flows (notably the Waipa) (Fig. 6c). A localised temperature increase was regularly observed downstream of Huntly where a thermal power station discharges heated water to the river (Fig. 1a and Fig. 6). Specific conductivity declined immediately below the Waipa River confluence, reflecting the low-conductivity water from this tributary, with most notable reductions apparent at higher flows (winter and autumn). In contrast, specific conductivity generally increased downstream of other tributaries (e.g. Mangawara Stream and Whangamarino River). Specific conductivity increased rapidly near the upstream extent of saltwater intrusion during spring and summer, usually around $140 \mathrm{~km}$ from Karapiro dam, and

Fig. 6. Surface water quality measurements collected using the Biofish during (a) Summer (March 2010), (b) Autumn (May 2010), (c) Winter (August 2010) and (d) Spring (November (black) / December (grey) 2010). Dashed lines represent locations of major tributaries to the lower Waikato River, and the approximate maximum upstream effect of tidal cycles on river levels. Numbers relate to locations listed in Fig. 1a. 
(a) Summer

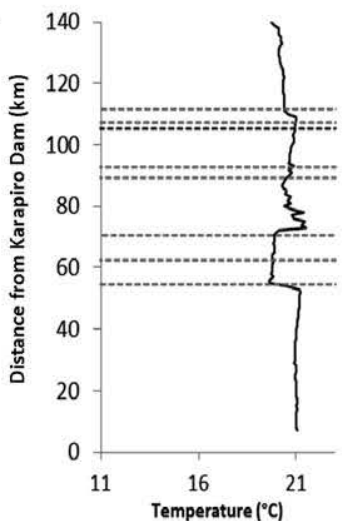

(b) Autumn

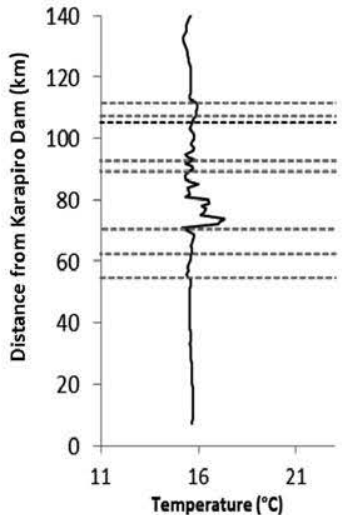

(c) Winter

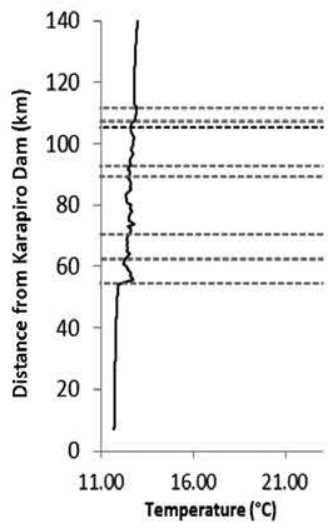

(d) Spring

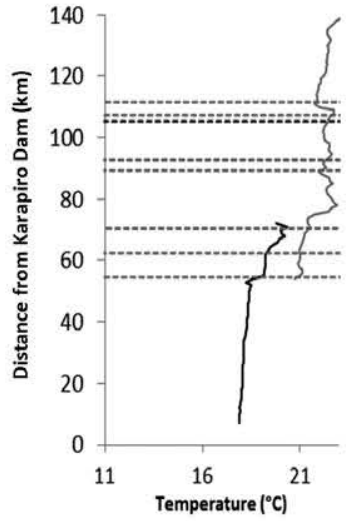

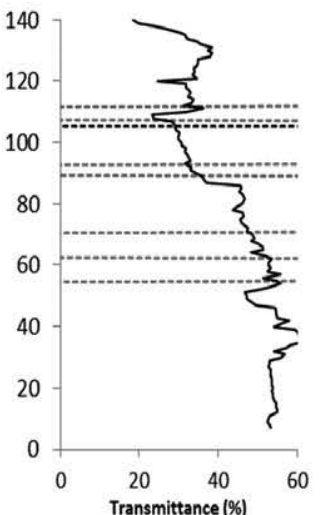
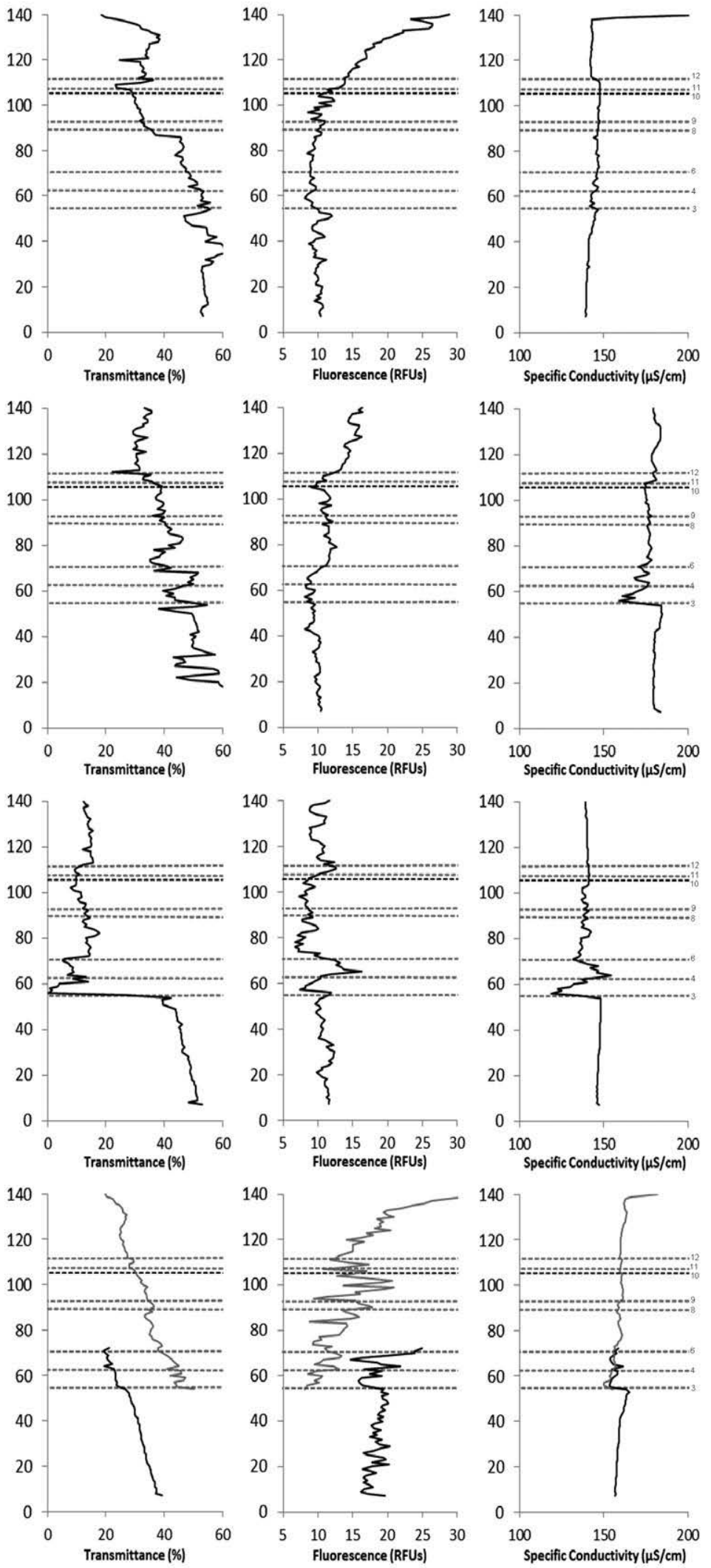
Table 2. Mean ( $\pm 1 \mathrm{SD}$ ) river water quality (annual) characteristics for clusters identified using SIMPROF routines (see Figs 7 \& 8). Superscripts denote percentage contribution to group structure $1,1-10 \% ; 2,11-20 \% ; 3,21-30 \%$ and so on.

\begin{tabular}{|c|c|c|c|c|c|c|}
\hline $\begin{array}{l}\text { Reach type } \\
\text { (Cluster) }\end{array}$ & Description & $\mathbf{n}$ & $\begin{array}{l}\text { Temperature } \\
\left({ }^{\circ} \mathrm{C}\right)\end{array}$ & $\begin{array}{l}\text { Specific } \\
\text { conductance } \\
(\mu \mathrm{S} / \mathrm{cm})\end{array}$ & $\begin{array}{l}\text { Chlorophyll } \\
\text { fluorescence (relative } \\
\text { fluorescence units) }\end{array}$ & $\begin{array}{l}\text { Light transmittance } \\
(\%)\end{array}$ \\
\hline W1 & $\begin{array}{l}\text { Relatively low specific conducti- } \\
\text { vity, water temperature, and light } \\
\text { attenuation }\end{array}$ & 37 & $16.62(0.03)^{1}$ & $156.39(0.65)^{4}$ & $12.3(0.34)^{2}$ & $48.02(2.26)^{5}$ \\
\hline W2 & $\begin{array}{l}\text { Similar to W1, with slightly } \\
\text { higher water temperature, and } \\
\text { light attenuation }\end{array}$ & 11 & $16.74(0.04)^{1}$ & $159.8(0.65)^{4}$ & $12.29(0.28)^{2}$ & $42.87(2.11)^{5}$ \\
\hline W3 & $\begin{array}{l}\text { Lowest specific conductivity, with } \\
\text { marked shift in other variables } \\
\text { compared to W1 and W2, } \\
\text { particularly at high flows }\end{array}$ & 8 & $17.18(0.05)^{1}$ & $148.42(3.6)^{9}$ & $9.16(0.36)^{1}$ & $37.35(2.9)^{1}$ \\
\hline W4 & Increase in reductions in $\mathrm{W} 3$ & 9 & $17.28(0.04)^{1}$ & $154.64(2.31)^{9}$ & $10.81(0.35)^{1}$ & $36.53(2.41)^{2}$ \\
\hline W5 & Increase in water temperature & 14 & $17.96(0.2)^{5}$ & $155.16(0.71)^{2}$ & $10.28(0.67)^{3}$ & $34.46(1.26)^{1}$ \\
\hline W6 & $\begin{array}{l}\text { Ongoing increase in reductions in } \\
\mathrm{W} 3 \text {, and dampened temperature } \\
\text { increase from in W5 }\end{array}$ & 22 & $17.83(0.11)^{2}$ & $155.56(0.5)^{1}$ & $11.39(0.93)^{6}$ & $29.13(1.92)^{2}$ \\
\hline W7 & $\begin{array}{l}\text { Increasing fluorescence and } \\
\text { reduce water clarity }\end{array}$ & 18 & $17.78(0.14)^{3}$ & $156.11(0.72)^{3}$ & $13.65(0.86)^{5}$ & $25.76(1.27)^{1}$ \\
\hline W8 & $\begin{array}{l}\text { Increasing fluorescence and } \\
\text { reduce water clarity }\end{array}$ & 8 & $17.72(0.02)^{1}$ & $157.39(0.34)^{1}$ & $16.3(0.77)^{9}$ & $27.12(0.45)^{1}$ \\
\hline W9 & $\begin{array}{l}\text { Increasing fluorescence and } \\
\text { reduce water clarity }\end{array}$ & 5 & $17.76(0.06)^{2}$ & $156.28(0.14)^{1}$ & $18.63(0.53)^{7}$ & $24.96(1.13)^{2}$ \\
\hline W10 & Increased fluorescence & $1 *$ & 17.85 & 160.47 & 21.25 & 22.15 \\
\hline W11 & Start of estuarine interface & $1 *$ & 17.89 & 176.77 & 22.05 & 20.93 \\
\hline Total & & 134 & $17.33(0.56)$ & $156.01(3.12)$ & $12.45(2.38)$ & $36.18(9.08)$ \\
\hline
\end{tabular}

for this reason, reaches from $141-143 \mathrm{~km}$ were not deemed "freshwater" and were excluded from further analysis (see Methods).

CLUSTER and SIMPROF analyses of seasonal water quality measurements identified a number of significant water quality reach types (groups) in each sampling season. When condensed to groups diverging at $>1$ Euclidean distance unit, there were 11 groups with significant internal structures using the annual average of measurements (Table 2, Figs. $7 \& 8$ ), and 8 to 16 for seasonal measurements (12 in summer, 9 in autumn, 8 in winter and 16 in spring; Fig. 9, and Table 3). The first and second axes of the PCO of annual water quality measurements explained $87.9 \%$ of variability in the data (Fig. 7), while for seasonal water quality measurements the first and second axes explained between 70 and $90 \%$ of the variation in each season, ranging from c. $40-80 \%$ on the first axis

Fig. 7. Principal coordinates ordination of reach types identified using CLUSTER and SIMPROF analyses of annual water quality measurements. See Table 2 for summary of variables for each reach type (W1-11).

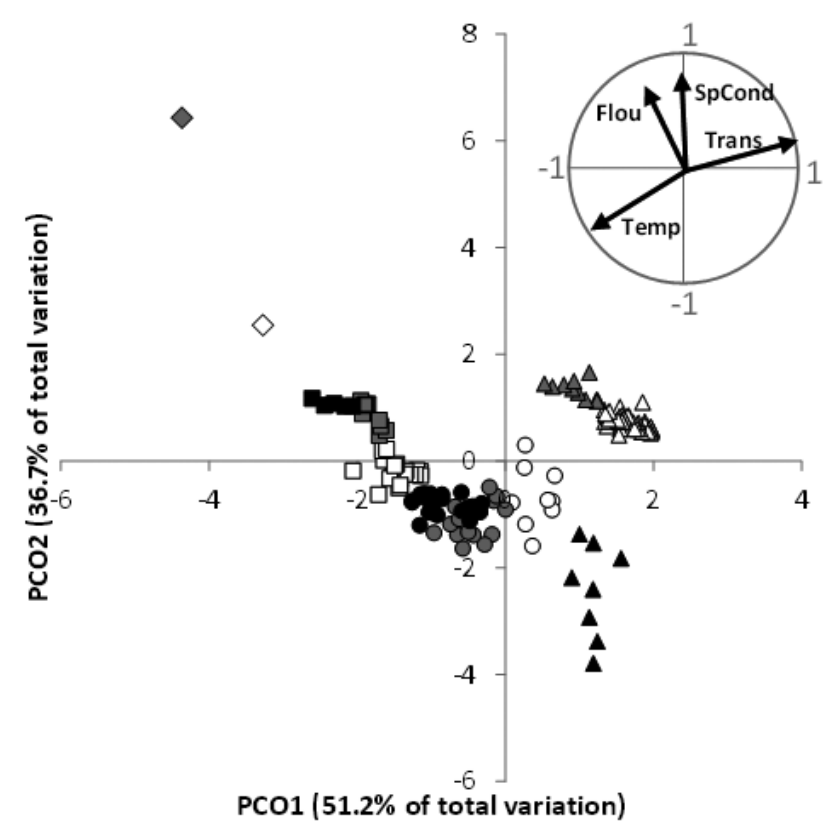

Key to reach types (Cluster): $W 1(\triangle), W 2(\Delta), W 3(\mathbf{A})$,

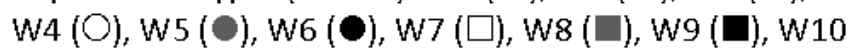
$(\diamond), W 11(\diamond)$ 
(a)

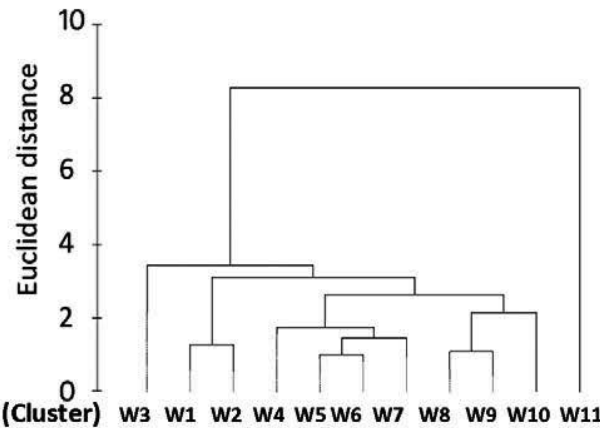

(b)

Reach type (Cluster) W3 W1 W2 W4 W5 W6 W7 W8 W9 W10 W11

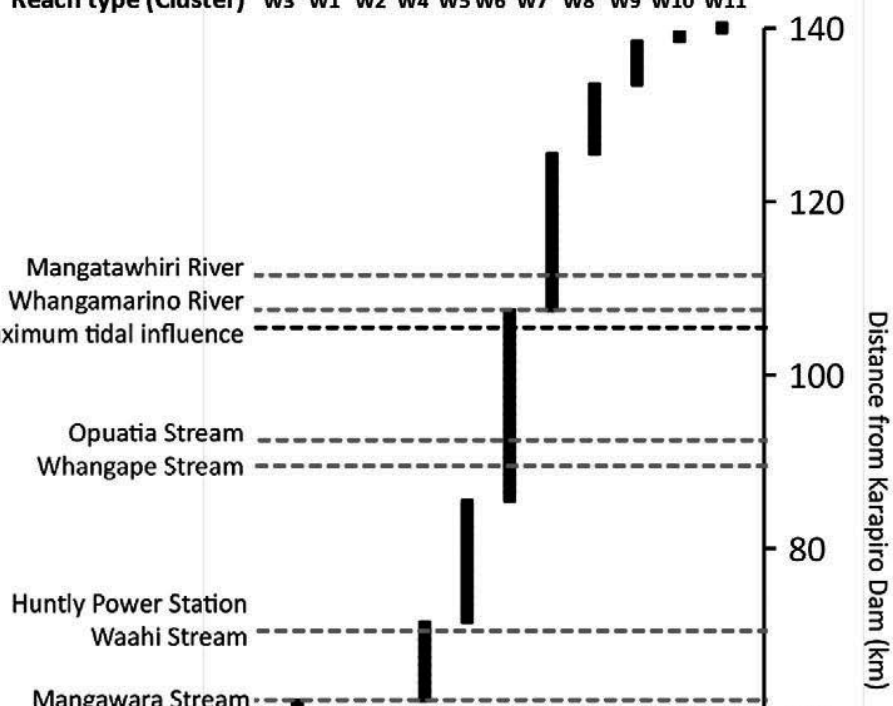

Estimated maximum tidal influence
Opuatia Stream
Whangape Stream
Huntly Power Station
Waahi Stream
Mangawara Stream.

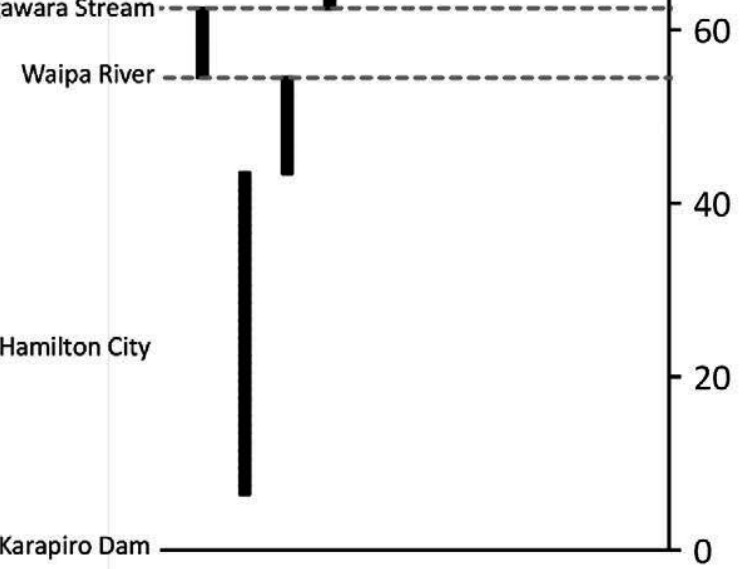

Fig. 8. (a) Dendrogram of relationships between reach types and (b) spatial arrangement of annual water quality reach types along surveyed section of the lower Waikato River. See Fig. 7 and Table 2 for characteristics of each reach type (W1-W11).

and c. $10-30 \%$ on the second axis (Fig. 10). The third PCO axis generally explained $<10 \%$, except in autumn when variation was similar to the second axis (c. 25\%). River reaches above the Waipa confluence (W1 and W2) grouped away from those below (W3 - W11) in PCO plots of annual measurements (Fig. 7), and in most seasons (Fig. 10), usually due to decreased transmittance and specific conductivity. This clustering of points was most pronounced during high winter and spring flows, and reflected marked differences in water clarity, as suggested by SIMPER analyses and Spearman correlation coefficients (Table 3 ). Reach types immediately below the Waipa confluence tended to reflect a decrease in specific conductivity and water temperature, as water from the Waipa mixed with the main flow (Figs. $6 \&$ 7). Except during winter, reach types typical of the tidally influenced 
Table 3. Summary characteristics of seasonal water quality clusters identified using SIMPROF routines (with a Euclidean distance of $<1$ ) for Summer (SM), Autumn (AT), Winter (WT) and Spring (SP).

\begin{tabular}{|c|c|c|c|c|c|}
\hline Cluster & n & $\begin{array}{l}\text { Temperature } \\
\left({ }^{\circ} \mathrm{C}\right)\end{array}$ & $\begin{array}{l}\text { Specific conductance } \\
(\mu \mathrm{S} / \mathrm{cm})\end{array}$ & $\begin{array}{l}\text { Chlorophyll fluorescence } \\
\text { (relative fluorescence units) }\end{array}$ & $\begin{array}{l}\text { Light transmittance } \\
(\%)\end{array}$ \\
\hline SM1 & 41 & $21.01(0.06)$ & $140.62(1.17)$ & $9.99(0.55)$ & $55.1(2.45)$ \\
\hline SM2 & 10 & $21.28(0.12)$ & $145.33(1.57)$ & $10.02(1.22)$ & $47.24(1.91)$ \\
\hline SM3 & 11 & $20.6(0.19)$ & $146.05(0.84)$ & $9.38(0.4)$ & $46.9(3.06)$ \\
\hline SM4 & 18 & $19.82(0.1)$ & $144.44(1.63)$ & $9.01(0.43)$ & $51.19(2.51)$ \\
\hline SM5 & 2 & $21.03(0.01)$ & $147.94(0.05)$ & $13.39(0.44)$ & $23.41(0.15)$ \\
\hline SM6 & 18 & $20.79(0.12)$ & $147.29(0.44)$ & $10.58(1.05)$ & $31.16(1.73)$ \\
\hline SM7 & 5 & $20.42(0.13)$ & $146.7(0.5)$ & $11.69(1.98)$ & $35.49(2.1)$ \\
\hline SM8 & 16 & $20.34(0.07)$ & $142.62(0.43)$ & $16.05(1.35)$ & $32.84(2.44)$ \\
\hline SM9 & 6 & $20.16(0.08)$ & $143.26(0.22)$ & $20.71(1.36)$ & $37.06(1.61)$ \\
\hline SM10 & 5 & $20.15(0.06)$ & $142.9(0.09)$ & $25.36(1.3)$ & $28.75(3.64)$ \\
\hline SM11 & 1 & $19.88(0)$ & $157.54(0)$ & $27.2(0)$ & $19.71(0)$ \\
\hline SM12 & 1 & $19.72(0)$ & $206.66(0)$ & $28.83(0)$ & $18.38(0)$ \\
\hline Total & 134 & $20.62(0.47)$ & $144.22(6.18)$ & $12.05(4.52)$ & $43.91(10.88)$ \\
\hline AT1 & 17 & $15.7(0.03)$ & $179.99(1.05)$ & $10.15(0.23)$ & $60.68(1.68)$ \\
\hline AT2 & 36 & $15.6(0.05)$ & $180.71(2.52)$ & $9.5(0.56)$ & $49.32(3.68)$ \\
\hline AT3 & 35 & $15.64(0.22)$ & $176.28(1.96)$ & $11.06(0.71)$ & $39.53(3.26)$ \\
\hline AT4 & 1 & $15.85(0)$ & $179.57(0)$ & $12.81(0)$ & $22.13(0)$ \\
\hline AT5 & 13 & $15.59(0.03)$ & $180.02(1.36)$ & $14.03(0.45)$ & 30.89 (1.09) \\
\hline AT6 & 15 & $15.38(0.1)$ & $181.92(1.86)$ & $15.42(0.69)$ & $32.71(2.15)$ \\
\hline AT7 & 9 & $15.52(0.1)$ & $167.03(4.33)$ & $8.77(0.51)$ & $44.69(3.71)$ \\
\hline AT8 & 4 & $16.44(0.12)$ & $177.47(0.93)$ & $12.08(0.45)$ & $41.07(2.05)$ \\
\hline AT9 & 4 & $16.89(0.52)$ & $177.37(1.03)$ & $11.62(0.16)$ & $35.76(0.67)$ \\
\hline Total & 134 & $15.66(0.31)$ & $178.41(4.23)$ & $11.21(2.12)$ & $43.39(9.66)$ \\
\hline WT1 & 48 & $11.8(0.06)$ & $147.23(0.79)$ & $47.03(3.28)$ & $10.95(0.75)$ \\
\hline WT2 & 4 & $12.54(0.11)$ & $127.46(4.35)$ & $2.54(1.64)$ & $8.22(0.74)$ \\
\hline WT3 & 3 & $12.45(0.15)$ & $134.12(2.17)$ & $12.29(11.9)$ & $11.6(0.81)$ \\
\hline WT4 & 33 & $12.75(0.21)$ & $140.11(2)$ & $13.23(2.29)$ & $10.58(0.83)$ \\
\hline WT5 & 7 & $12.58(0.15)$ & $138.1(2.53)$ & $14.63(1.98)$ & $7.15(0.35)$ \\
\hline WT6 & 32 & $12.71(0.15)$ & $139.09(1.47)$ & $12.64(1.75)$ & $8.56(0.49)$ \\
\hline WT7 & 6 & $12.47(0.07)$ & $146.07(4.84)$ & $8.04(0.89)$ & $13.47(1.54)$ \\
\hline WT8 & 1 & $12.77(0)$ & $118.7(0)$ & $0.21(0)$ & $11.91(0)$ \\
\hline Total & 134 & $12.37(0.45)$ & $141.9(5.43)$ & $10.14(1.61)$ & $24.6(17.22)$ \\
\hline SP1 & 1 & $17.88(0)$ & $156.7(0)$ & $19.59(0)$ & $39.43(0)$ \\
\hline SP2 & 22 & $18(0.07)$ & $157.64(0.5)$ & $17.75(1.27)$ & $35.2(1.48)$ \\
\hline SP3 & 14 & $18.2(0.09)$ & $159.43(0.44)$ & $18.5(0.61)$ & $31.56(0.8)$ \\
\hline SP4 & 11 & $18.39(0.1)$ & $162.98(1.04)$ & $19.45(0.42)$ & $28.67(1.05)$ \\
\hline SP5 & 14 & $19.47(0.38)$ & $155.25(1.54)$ & $17.32(1.53)$ & $22.64(1.31)$ \\
\hline SP6 & 3 & $19.93(0.43)$ & $158.71(2.62)$ & $23.19(1.2)$ & $19.42(0.26)$ \\
\hline SP7 & 1 & $19.77(0)$ & $158.57(0)$ & $24.94(0)$ & $21.06(0)$ \\
\hline Total & 66 & $18.53(0.69)$ & $158.45(2.67)$ & $18.48(1.86)$ & $29.81(5.54)$ \\
\hline
\end{tabular}


Table 3. cont.

\begin{tabular}{llllll}
\hline Cluster & $\mathbf{n}$ & $\begin{array}{l}\text { Temperature } \\
\left({ }^{\circ} \mathbf{C}\right)\end{array}$ & $\begin{array}{l}\text { Specific conductance } \\
(\boldsymbol{\mu S} / \mathbf{c m})\end{array}$ & $\begin{array}{l}\text { Chlorophyll fluorescence } \\
(\text { relative fluorescence units) }\end{array}$ & $\begin{array}{l}\text { Light transmittance } \\
(\%)\end{array}$ \\
\hline SP8 & 8 & $21(0.09)$ & $152.87(1.9)$ & $9.49(0.93)$ & $44.96(1.81)$ \\
\hline SP9 & 11 & $21.22(0.17)$ & $156.28(0.56)$ & $11.74(1.25)$ & $41.17(2.44)$ \\
\hline SP10 & 2 & $21.6(0.26)$ & $158.33(0.24)$ & $9.3(0.08)$ & $38.33(1.12)$ \\
\hline SP11 & 28 & $22.44(0.21)$ & $159.9(1.08)$ & $13.76(2.32)$ & $34.03(2.26)$ \\
\hline SP12 & 10 & $21.93(0.12)$ & $160.09(0.35)$ & $14.02(1.16)$ & $27.15(1.44)$ \\
\hline SP13 & 22 & $22.39(0.14)$ & $161.54(1.31)$ & $19.17(1.83)$ & $27.41(2.99)$ \\
\hline SP14 & 1 & $23.06(0)$ & $165.52(0)$ & $30.95(0)$ & $20.4(0)$ \\
\hline SP15 & 3 & $22.68(0.18)$ & $162.59(0.41)$ & $26.65(1.73)$ & $22.83(0.48)$ \\
\hline SP16 & 1 & $23.24(0)$ & $181.64(0)$ & $31.38(0)$ & $19.72(0)$ \\
\hline Total & 87 & $22.08(0.59)$ & $159.6(3.79)$ & $15.27(4.9)$ & $32.85(6.92)$ \\
\hline
\end{tabular}

section of river grouped away from most of those upstream (Fig. 10), apparently due to increasing fluorescence (Fig. 6), and occasionally due to higher specific conductivity at river reach $140 \mathrm{~km}$ during summer (see group SM12 in Fig. 10). The upstream extent of tidal influence on groups appeared to vary with flow conditions, and during low autumn flows two sites at the downstream end of the fluvial section aligned more closely with tidally influenced river reaches (Fig. 10). This indicates that the effect on water quality of the upstream amplitude of the tidal cycle is likely to vary between seasons and in response to flow conditions upstream. During high winter flows, however, there appears to be little effect of the tidal cycle on water quality measurements at the downstream end of the surveyed section of river, $140 \mathrm{~km}$ from Karapiro dam. Higher water temperatures were evident immediately downstream of Huntly at low flows (Fig. 10) and subsequently these reaches were characterised as significant groups in CLUSTER analyses (Fig. 9). Conversely, tributaries appeared to contribute cooler water to the main stem during summer and autumn (Fig. 6c).

Cluster groups above the Waipa confluence were most closely related to each other than they were to those below and were unique to that part of the river based on the annual average (Fig. 8a), a pattern generally supported in each season (Fig. 9). SIMPER analyses indicated that clusters of river reaches above the Waipa River could generally be distinguished from those immediately below, as they were associated with higher water clarity and specific conductivity (Table 2; Table 3 ). However, at lower autumn flows some clusters downstream of the Waipa were also closely related to those above, and some water quality reach types occurred both above and below the Waipa confluence (Fig. 8b). This was most apparent when the Waipa contributed a relatively small volume to the main stem flow. At this time reaches immediately downstream of the confluence belonged to a distinct cluster group, and the dominant cluster type from above the confluence reappeared further downstream. Conversely, during winter and spring when flows from the Waipa were high, groups above the confluence did not persist downstream (Figs. 9c, d).

Cluster groupings were often present downstream of tributary confluences, most notably the Waipa (driven by low water clarity and specific conductance as described above), but also for smaller tributaries such as the Mangawara Stream (Fig. 9). Tributary confluences other than the Waipa tended to belong to groups characterised by increased chlorophyll fluorescence and conductivity (Figs. 6 and 9). Unique groups did exist in the tidal freshwater section of the lower river, generally reflecting higher fluorescence measurements, and the upstream extent of groups unique to the tidally influenced region was greatest at low autumn flows.

Fig. 9. Dendrogram and spatial arrangement of significant groups identified by PRIMER SIMPROF and CLUSTER routines for surface water quality measurements collected using the Biofish during (a) Summer (March 2010), (b) Autumn (May 2010), (c) Winter (August 2010) and (d) Spring (November/December 2010, separated by black line). Dotted red lines represent locations of major tributaries to the lower Waikato River. 
(a) Summer

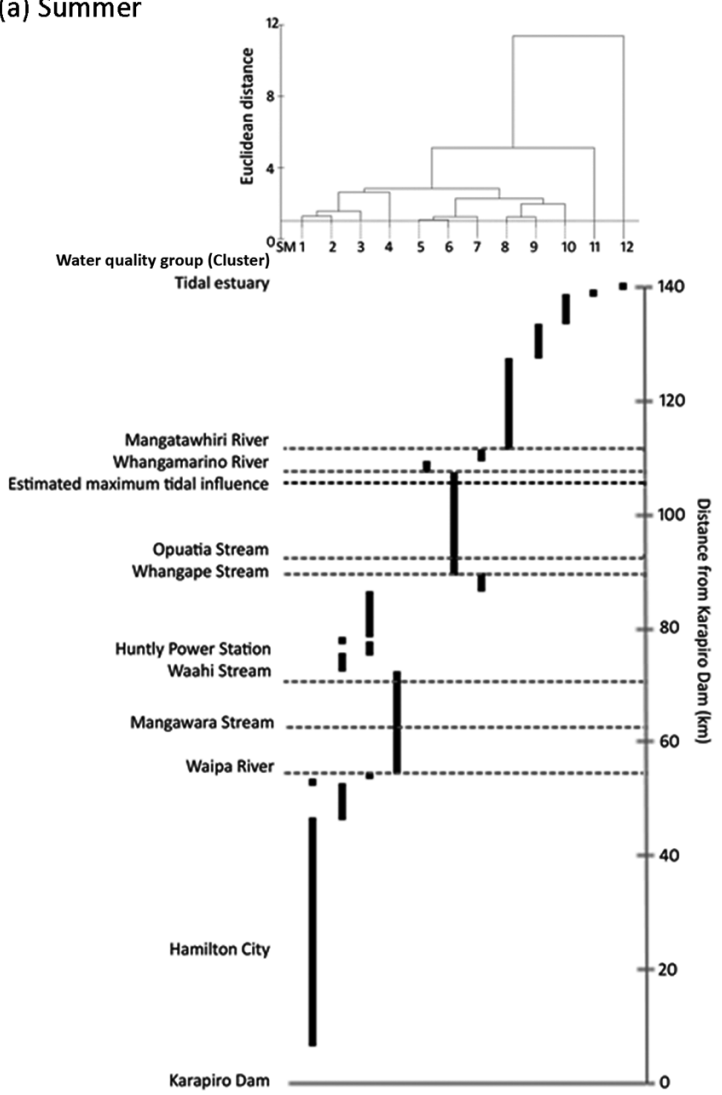

(c) Winter

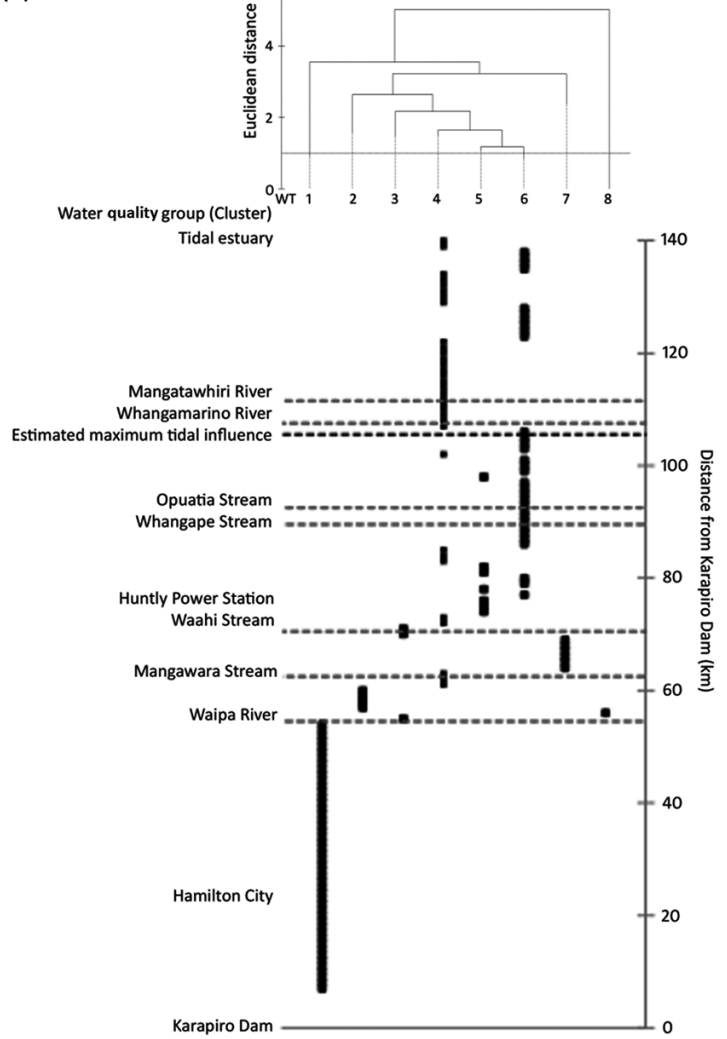

(b) Autumn
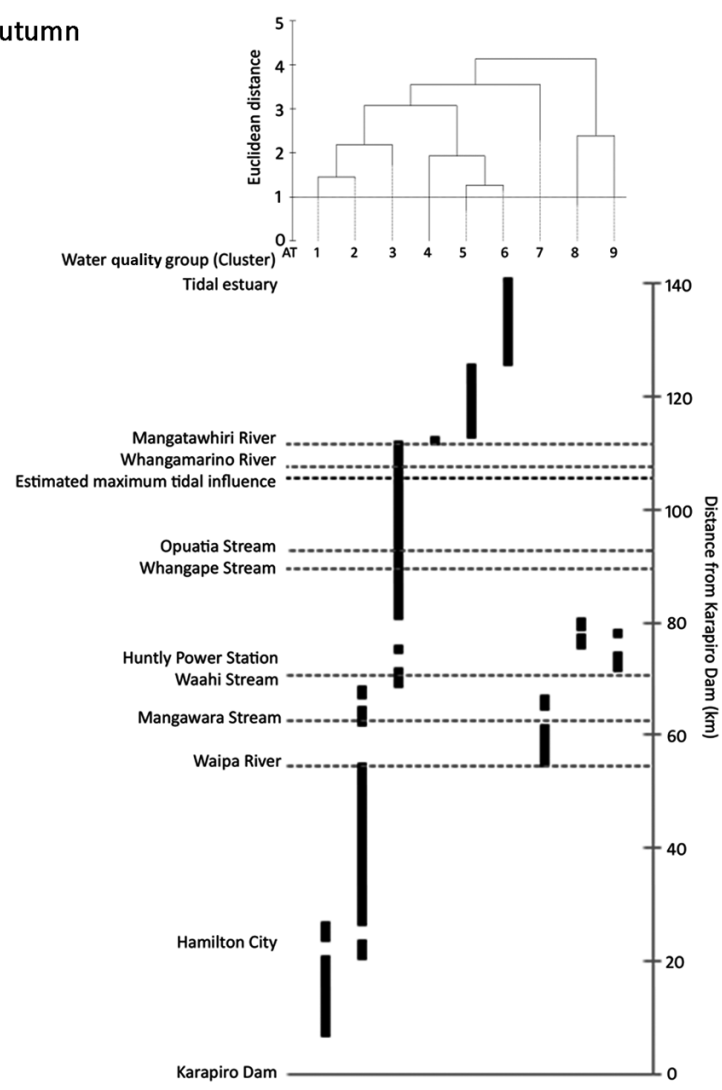

(d) Spring

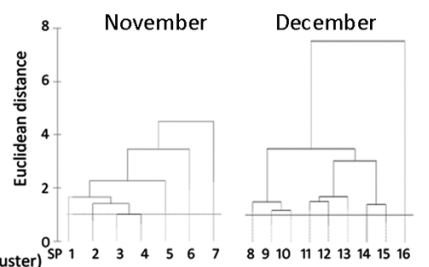

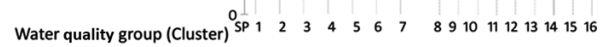

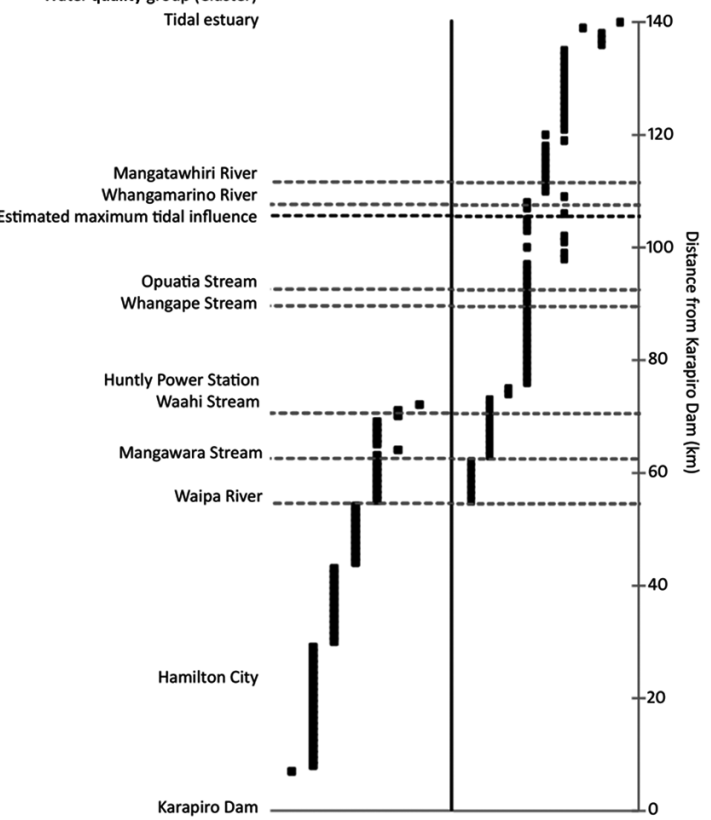




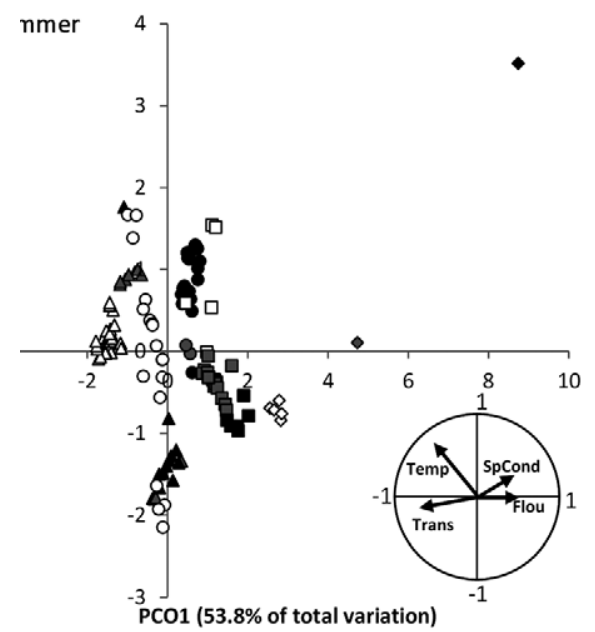

(b) Autumn
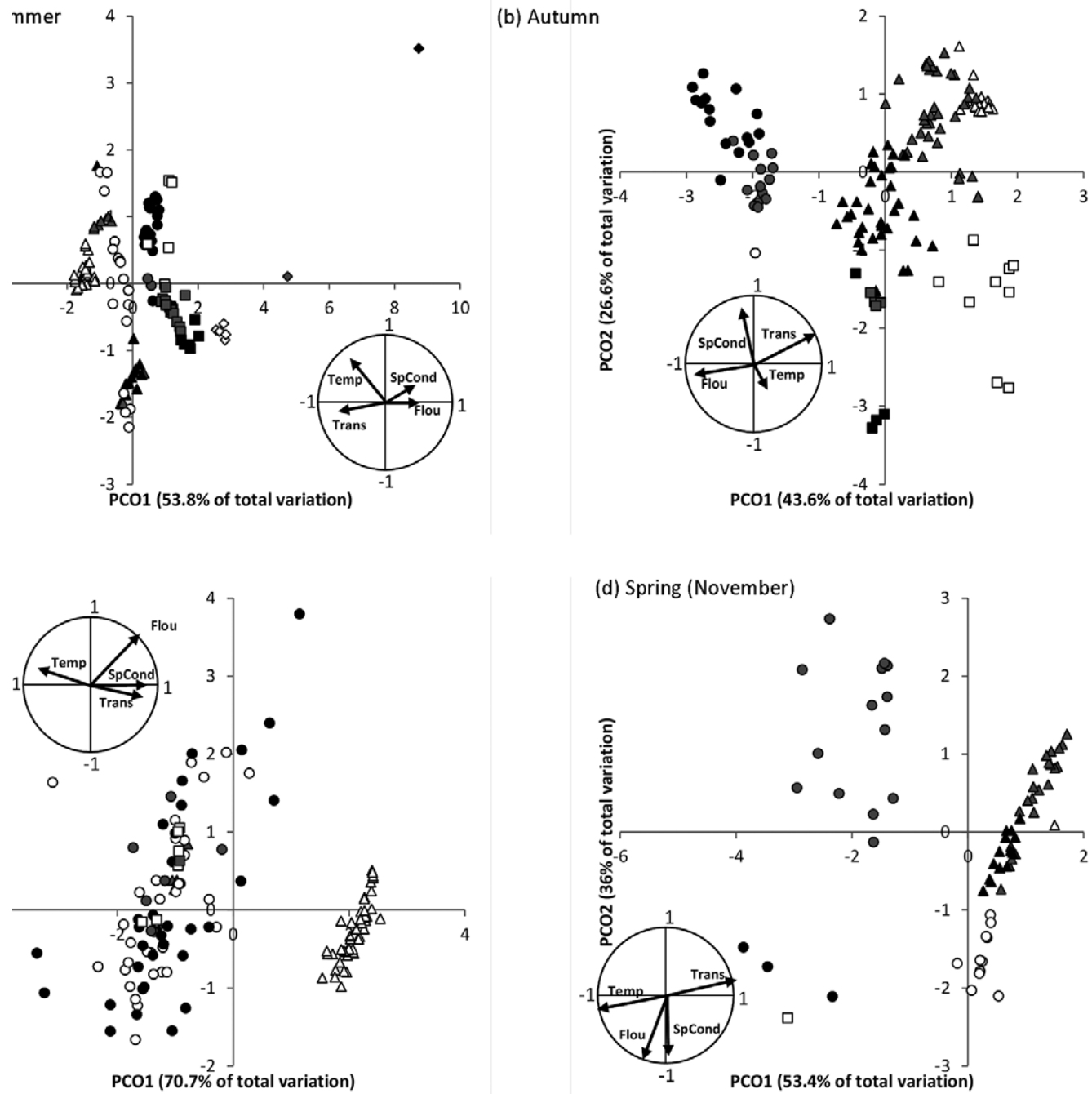

'ROF clusters derived from water quality measurements

$\Delta 2 \Delta 304 \bullet 5 \bullet 6 \square 7 \square 8 \square 9 \diamond 10 \diamond 11 \bullet 12$

Fig. 10. Principal coordinates ordination of two most important axes of water quality measurements collected using the Biofish during (a) March, (b) May, (c) August, and the two spring surveys (d) November, and (e) December. Symbols denote groups identified by SIMPROF analyses (up to 12). Inserts represent vector diagrams of Spearman correlation coefficients (arrows) for water clarity (Trans), specific conductance (SpCond), chlorophyll fluorescence (Flou) and water temperature (Temp).

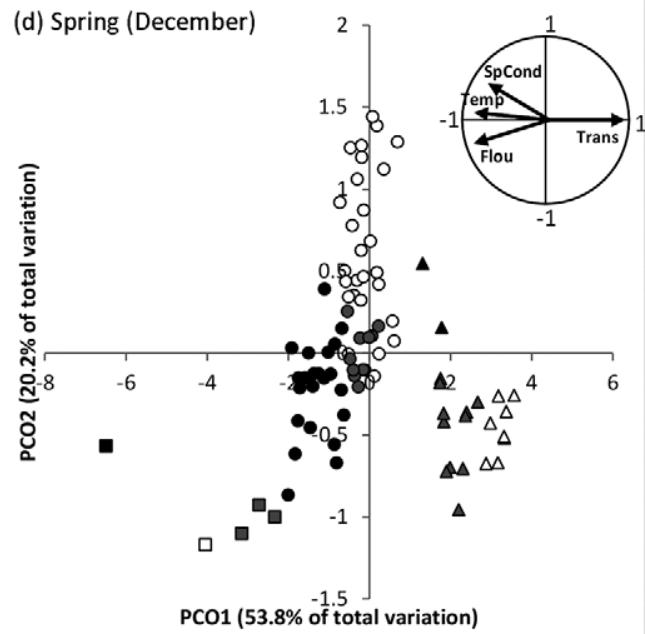




\section{Discussion}

\section{Definition of spatial units}

Multivariate statistical approaches are useful for interpreting and evaluating complex datasets (Varol et al. 2011), and were successful in our study for discriminating spatial units with similar environmental character along the lower Waikato River. Using this framework to analyse high intensity data from physical measurements of $1-\mathrm{km}$ long polygons and from sensor arrays measuring seasonal water quality every 25 seconds resolved 7 or 11 spatial units, respectively. Water quality patterns were represented by differences in clarity, chlorophyll fluorescence and specific conductance driven by tributary inflows in the mid-section of the river and tidal cycles in the lower section. The identified water quality patterns support those documented by previous measurements of turbidity and concentrations of nitrogen, phosphorus, water column chlorophyll a and dissolved colour (Vant 2010), and also patterns in phytoplankton biomass observed by Lam (1981) which peaked in the tidal freshwater section of the river and decreased immediately below the Waipa River. Patterns of channel character were largely shaped by the depth and lateral complexity of constituent river reaches, with boundaries partly reflecting geomorphic features constraining the main channel (e.g., Taupiri Gap). However, longitudinal changes in environmental pattern were not necessarily abrupt and some reflected a transition in geomorphology or, for water quality, prevailing flow conditions. Tributary inflows to the lower Waikato River also tend to be enriched in nutrients and sediment from the surrounding agricultural catchment, especially those draining lakes which tend to be highly eutrophic and can drive localised patterns in main stem chlorophyll $a$ (Hamilton et al. 2010).

Large rivers provide an interface with coastal environments and are therefore strongly influenced by tidal fluctuations in their lower reaches, adding hydrological complexity that can affect both the morphology of the river channel and biological production (Ensign et al. 2012). These sections of river, where water flow is affected by the tidal cycle but remains fresh, can extend upstream for tens to hundreds of kilometres (e.g. Howarth et al. 1996). Similar to studies of smaller coastal rivers (Ensign et al. 2012), a significant divergence in river morphology began around one- third of the way into the tidally influenced freshwater section. Moreover, flood control works and channel modification in the lower Waikato River may have led to an increase in the upstream extent of the tidal influence by around $10 \mathrm{~km}$, with historical tidal influence previously closer to the delta (Van Kampen 2010). The effect of tidal cycles was evident on the freshwater section of the lower Waikato River, both in terms of physical complexity and water quality measurements, with greater river width, depth and shoreline complexity, and elevated seasonal mean chlorophyll fluorescence indicating greater phytoplankton abundance. Phytoplankton biomass is strongly dependent on fluvial discharge and the residence time available for community development in tidally influenced freshwater sections of rivers (Neal et al. 2006). High biomass often occurs at low flows (Bennett et al. 1986) when water travel times can be many times greater than in non-tidal river sections (Ensign et al. 2012). Production is also closely linked to channel form, with broad channels and extensive shallow lateral areas, such as those in the delta, providing favourable light and flow retention conditions for algal growth (Bukaveckas et al. 2011a), which in turn can enhance zooplankton growth in tidal systems (Müller-Solger et al. 2002). These findings highlight interactions between hydrology, water quality and the physical structure of channels in tidal river sections, supporting their identification as discrete spatial units for management. Boundaries between strictly fluvial and tidal freshwater sections are likely to be transitional, variable and sometimes indistinct due to the nature and strength of daily tidal cycles, and flow conditions.

Although seasonal averages were used to define spatial units based on water quality measurements, the number of units and location of boundaries differed between seasons. Substantial increases in sediment loads supplied by major tributaries may occur with seasonal high flows, while high flows in the main channel can also overwhelm the contributions of smaller tributaries (Boyer et al. 2010). Water temperature also plays an important role in primary production, with increased seasonal temperature and light availability linked to elevated rates of photosynthesis, respiration and metabolism in other large lowland rivers (Descy et al. 1987). In our study and that of Lam (1981), measurements of phytoplankton biomass (chlorophyll fluorescence in our study) were recorded during summer and spring when water temperatures were warmest, particularly in the tidal freshwater zone. The discontinuity between the river sections dominated by clear, dam-fed water of the Waikato River and the Waipa River, which contributes significant amounts of flow and sediment at high flows (Brown 2010), was most distinct during winter and spring (high flows) and less so during summer and autumn (low flows). High river flows in the main channel can also have a dampening effect on tidal cycles and upstream extent of saline intrusion into freshwater sections of lowland rivers (Anderson \& Lockaby 2012). Tidal cycle fluctuations at Tuakau (Fig. 1a) were greatest during months of lower fluvial flows (Fig. 1d), and this is reflected in the transition from fluvial to tidal water quality reach types being shortest and furthest upstream during summer and autumn (Fig. 9). Conversely 
during high winter flows a transition was undetectable and daily water level fluctuations were also small (Fig. 1d).

The identified channel units correspond to some extent to known variations in biological patterns within the lower river. Collier et al. (2014) reported an abrupt decrease in benthic macroinvertebrate biodiversity at Huntly downstream of the geomorphic channel constriction at Taupiri, and hypothesised that this reflected deposition of sediment delivered to the main channel from the Waipa River. Increases in suspended sediment are also likely to affect downstream food webs (Henley et al. 2000), and it has been suggested that lower invertebrate densities below the Waipa confluence during winter and spring may be a result of less suitable flow and growth conditions (Collier et al. 2011), while the growth and food assimilation of key primary consumers in the lower Waikato River, such as Potamopyrgus antipodarium, can be adversely affected by high sediment to food ratios (Broekhuizen et al. 2001). Similarly, changes in stable isotope signatures and differences in carbon utilisation by aquatic biota have been observed between sites from different sections of the lower Waikato River (i.e. fluvial reaches above the Waipa confluence, those below, and tidal freshwater reaches) (Pingram et al. 2014). Littoral macroinvertebrate communities have also been reported to respond to localised effects of organic matter, sediment and thermal discharges but not to clinal gradients, suggesting that physical heterogeneity of river edges is not a key factor structuring community composition (Collier et al. 2014). Physical channel complexity may be more relevant for riverine fish which use lateral habitats during various lifecycle stages (Górski et al. 2014), and as lateral habitats can represent a key location for carbon transfer through food webs (Pingram et al. 2014). Laterally complex river zones are likely to have a greater array of habitats where abiotic characteristics and biotic function are driven by the frequency, magnitude and duration of main channel flow and flood pulses (Schiemer \& Hein 2007; Thorp et al. 2008). Reduced flow velocities and increased water retention in these habitats are important factors in the processing of nutrients and organic carbon by plankton before transfer to other parts of the food web (Schiemer et al. 2001; Górski et al. 2013). Smaller retention zones can be created by changes in shoreline configuration, with increasing shoreline complexity (e.g., length, sinuosity) leading to reduced current velocities and longer retention times that benefit some littoral organisms (Schiemer et al. 2001; Schiemer \& Hein 2007).

\section{Role of discontinuities}

Our Waikato River case study has highlighted the importance of network, geomorphic and anthropogenic discontinuities to the spatial structure of river sections. While geomorphic constrictions defined the boundaries of some physical units, adjoining tributaries from the wider river network often interrupted broader spatial patterns of water quality units and in one instance defined a boundary in the main stem between reaches above and below the tributary inflow. Tributary junctions can create additional complexity in the main river, with a complex range of associated effects on woody debris abundance, substrate heterogeneity, consumer abundance, water volume, nutrient availability, sediment loading, and bed particle shape and size that can in turn create nodes of high habitat complexity, biological diversity and productivity (Kiffney et al. 2006; Rice et al. 2006; Rosales et al. 2007). The relative impact and extent of discontinuities and complexity in the main river caused by tributary junctions will depend on temporal and spatial flow variability. For example, the distribution and intensity of rainfall in the catchments of large tributaries can mediate the delivery of sediment, allochthonous carbon sources and woody debris to rivers (Rice et al. 2006).

In our study there was a clear discontinuity between river reaches above and below the confluence of the largest tributary, the $5^{\text {th }}$ order Waipa River, for all water quality measurements taken, particularly at high flows (winter and spring). Depending on the relative flow conditions in the main stem, minor discontinuities were also apparent around smaller tributaries, usually denoted by increased chlorophyll fluorescence or specific conductivity. Lakeand wetland-fed tributaries in particular tended to have localised positive effects on phytoplankton biomass in the main stem, while the Waipa tended to reduce chlorophyll fluorescence. The differential effects of tributaries on main stems, dependent on donor concentrations of algae and magnitude of flow, have also been noted by other workers in terms of positive (Bukaveckas et al. 2011b) or negative (Descy et al. 1987; Bukaveckas et al. 2011b) effects on main stem phytoplankton biomass. The downstream extent of tributary influence on water quality will likely depend on flow volumes and velocities of both the contributing source and the receiving main channel (Rice et al. 2008). Direct human influences were also noted around a thermal discharge (at Huntly; Fig. 1a), which measurably increased water temperature, leading to a distinct group of reaches immediately downstream of the discharge. However, these smaller network and anthropogenic discontinuities did not have an over-riding effect on spatial clustering, and reaches further downstream tended to belong to the predominant group upstream of the minor 
discontinuity. Such localised changes can be considered as 'noise' within a given river 'link', as defined by Rice et al. (2001), since they do not lead to a significant shift in main stem character. Nevertheless, major discontinuities caused by significant tributary contributions of flow and sediment can significantly affect spatial patterns of biological communities (Collier et al. 2014).

Large dams also represent significant discontinuities along large rivers, leading to marked downstream changes in ecosystem function, including reduced flow pulses and transported sediments, increased channel incision leading to disconnection of lateral habitats, changes in water temperature and releases of lake-derived plankton (Ward \& Stanford 1983; Górski et al. 2011). Moreover, fluctuations as a result of diurnal hydro-power generation can have impacts on the species richness, abundance and behaviour of macroinvertebrates and fish (Bunn \& Arthington 2002). The rate of downstream recovery from these effects will be dependent on the magnitude of regulation (Cortez et al. 2012) and the presence of large unregulated downstream tributaries (Stanford \& Ward 2001), such as the Waipa River in this study. Flow variability above the Waipa confluence is regulated by the dam at Karapiro (Fig. 1b) and high water clarity partly reflects the retention of suspended solids in the series of eight upstream hydro lakes, which has also led to increased bed incision downstream, although the river channel maintains its natural shape (Hicks \& Hill 2010).

\section{Conclusions}

Multivariate statistical approaches and geographic tools provided a powerful means for condensing our spatially intensive dataset and guided identification of river units for future ecological management and research. Channel units were distinguished by both riverscape features and physico-chemical parameters which did not necessarily align and sometimes had indistinct boundaries. Lateral channel complexity and depth played an important role in shaping physical patterns, while features such as large tributaries and tidal influences had substantial roles in shaping water quality patterns. The boundaries of potential zones may have been different in the past and could change again as a result of improvements to current land management practices or rising sea levels. As aerial and high resolution satellite photos become more widely available during different seasons and flow conditions, further analyses could be conducted to quantify temporal variability in physical complexity metrics, as recommended by the authors of the RCCR (O'Neill \& Thorp 2011). Our results can also be seen in the context of a developed river whereby the anthropogenic impacts such as large dams (increased water clarity and incision), thermal power stations (heated discharges), and land clearance for pastoral grazing (increased suspended sediments and hydrological extremes) can affect the ecological integrity of a fluvial system and the composition of contemporary management units. Management objectives should reflect the dynamic spatial and temporal nature of rivers (Elosegi et al. 2010) which can create fuzzy or shifting boundaries between hydrogeomorphic units. The scale of potential units identified in this case study, generally more than several kilometres in length, is relevant for management because these units integrate an ecologically meaningful combination of properties likely to shape ecosystem processes such as energy transfer in food webs. Given that actions and targets may differ between physical channel and water quality management, spatial units (reach types) identified for each of these do not necessarily need to directly coincide from a management or research perspective, although both should be considered in decision making and experimental design.

\section{Acknowledgements}

The authors acknowledge funding provided by the University of Waikato Strategic Investment Fund for the costs of sample collection. We thank Warrick Powrie and Dudley Bell for driving boats, and Mathew Allan and Chris McBride for assistance with GIS and Biofish, respectively. The University of Waikato provided a doctoral student scholarship. We thank Professor James Thorp and two anonymous reviewers who provided comments that helped improve this manuscript.

\section{References}

Anderson, C.J. \& Lockaby, B.G. (2012): Seasonal patterns of river connectivity and saltwater intrusion in tidal freshwater forested wetlands. - River Res. Appl. 28: 814-826.

Anderson, M.J., Gorley, R.N. \& Clarke, K.R. (2008): PERMANOVA+ for PRIMER: guide to software and statistical methods. - In: Primer-e, Plymouth, UK, pp. 214.

Bennett, J.P., Woodward, J.W. \& Shultz, D.J. (1986): Effect of discharge on the chlorophyll $a$ distribution in the tidally-influenced Potomac River. - Estuaries 9: 250-260.

Boyer, C., Verhaar, P.M., Roy, A.G., Biron, P.M. \& Morin, J. (2010): Impacts of environmental changes on the hydrology and sedimentary processes at the confluence of St. Lawrence tributaries: potential effects on fluvial ecosystems. Hydrobiologia 647: 163-183.

Broekhuizen, N., Parkyn, S. \& Miller, D. (2001): Fine sediment effects on feeding and growth in the invertebrate grazers Potamopyrgus antipodarum (Gastropoda, Hydrobiidae) and 
Deleatidium sp. (Ephemeroptera, Leptophlebiidae). - Hydrobiologia 457: 125-132.

Brown, E.J. (2010): Flow regime and water use. - In: Collier, K.J., Hamilton, D.P., Vant, W.N. \& Howard-Williams, C. (eds.): The Waters of the Waikato: Ecology of New Zealand's longest river. - Environ. Waikato and Centre Biodivers. Ecol. Res. (The University of Waikato). Hamilton, pp. 29-46.

Bukaveckas, P., Barry, L., Beckwith, M., David, V. \& Lederer, B. (2011a): Factors determining the location of the chlorophyll maximum and the fate of algal production within the tidal freshwater James River. - Estuaries Coasts 34: 569-582.

Bukaveckas, P., MacDonald, A., Aufdenkampe, A., Chick, J., Havel, J., Schultz, R., Angradi, T., Bolgrien, D., Jicha, T. \& Taylor, D. (2011b): Phytoplankton abundance and contributions to suspended particulate matter in the Ohio, Upper Mississippi and Missouri Rivers. - Aquat. Sci. 73: 419-436.

Bunn, S.E. \& Arthington, A.H. (2002): Basic principles and ecological consequences of altered flow regimes for aquatic biodiversity. - Environ. Manage. 30: 492-507.

Chang, H. (2008): Spatial analysis of water quality trends in the Han River basin, South Korea. - Water Research 42: 32853304.

Collier, K.J., Watene-Rawiri, E.M. \& McCraw, J.D. (2010): Geography and history. - In: Collier, K.J., Hamilton, D.P., Vant, W.N. \& Howard-Williams, C. (eds.): The Waters of the Waikato: Ecology of New Zealand's longest river. - Environ. Waikato and Centre Biodivers. Ecol. Res. (The University of Waikato), pp. 1-12.

Collier, K.J., Hamer, M.P. \& Davenport, M.W. (2011): Artificial substrate monitoring of macroinvertebrates in the Waikato River: 25 years on. - Waikato Regional Council Technical Report 2011/25.

Collier, K.J., Clapcott, J.E., David, B.O., Death, R.G., Kelly, D., Leathwick, J.R. \& Young, R.G. (2012): Macroinvertebrate pressure relationships in boatable New Zealand rivers: Influence of underlying environment and sampling substrate. - River Res. Appl. 29: 645-659.

Collier, K.J., Hamer, M.P. \& Moore, S.C. (2014): Littoral and benthic macroinvertebrate community responses to contrasting stressors in a large New Zealand river. - N. Z. J. Mar. Fresh. (in press)

Cortez, D.P., Growns, I.O., Mitrovic, S.M. \& Lim, R.P. (2012): Effects of a gradient in river regulation on the longitudinal trends in water quality and benthic algal and macroinvertebrate assemblages in the Hunter River, Australia. - Mar. Freshw. Res. 63: 494-504.

Descy, J.P., Servais, P., Smitz, J.S., Billen, G. \& Everbecq, E. (1987): Phytoplankton biomass and production in the river meuse (Belgium). - Water Research 21: 1557-1566.

Dolédec, S., Phillips, N. \& Townsend, C. (2011): Invertebrate community responses to land use at a broad spatial scale: trait and taxonomic measures compared in New Zealand rivers. - Freshwat. Biol. 56: 1670-1688.

Elosegi, A., Díez, J. \& Mutz, M. (2010): Effects of hydromorphological integrity on biodiversity and functioning of river ecosystems. - Hydrobiologia 657: 199-215.
Ensign, S.H., Doyle, M.W. \& Piehler, M.F. (2012): Tidal geomorphology affects phytoplankton at the transition from forested streams to tidal rivers. - Freshwat. Biol. 57: 21412155 .

Eyre, B.D. \& Pepperell, P. (1999): A spatially intensive approach to water quality monitoring in the Rous River catchment, NSW, Australia. - J. Environ. Manage. 56: 97-118.

Górski, K., van den Bosch, L.V., van de Wolfshaar, K.E., Middelkoop, H., Nagelkerke, L.A.J., Filippov, O.V., Zolotarev, D.V., Yakovlev, S.V., Minin, A.E., Winter, H.V., De Leeuw, J.J., Buijse, A.D. \& Verreth, J.A.J. (2011): Post-damming flow regime development in a large lowland river (Volga, Russian Federation): Implications for floodplain inundation and fisheries. - River Res. Appl. 28: 1121-1134.

Górski, K., Collier, K.J., Duggan, I.C., Taylor, C.M. \& Hamilton, D.P. (2013): Connectivity and complexity of floodplain habitats govern zooplankton dynamics in a large temperate river system. - Freshwat. Biol. 58: 1458-1470.

Górski, K., Collier, K.J., Hamilton, D.P. \& Hicks, B.J. (2014): Effects of flow on lateral interactions of fish and shrimps with off-channel habitats in a large river-floodplain system. - Hydrobiologia 729: 161-174.

Hadwen, W.L., Fellows, C.S., Westhorpe, D.P., Rees, G.N., Mitrovic, S.M., Taylor, B., Baldwin, D.S., Silvester, E. \& Croome, R. (2010): Longitudinal trends in river functioning: patterns of nutrient and carbon processing in three Australian rivers. - River Res. Appl. 26: 1129-1152.

Hamilton, D.P., Vant, W.N. \& Neilson, K.A. (2010): Lowland lakes. - In: Collier, K.J., Hamilton, D.P., Vant, W.N. \& Howard-Williams, C. (eds.): The Waters of the Waikato: Ecology of New Zealand's longest river. - Environ. Waikato and Centre Biodivers. Ecol. Res. (The University of Waikato), pp. 245-264.

Henley, W.F., Patterson, M.A., Neves, R.J. \& Lemly, A.D. (2000): Effects of sedimentation and turbidity on lotic food webs: a concise review for natural resource managers. Rev. Fish. Sci. 8: 125-139.

Hicks, D.M. \& Hill, R.B. (2010): Sediment regime: sources, transport and changes in the riverbed. - In: Collier, K.J., Hamilton, D.P., Vant, W.N. \& Howard-Williams, C. (eds.): The Waters of the Waikato: Ecology of New Zealand's longest river. - Environ. Waikato and Centre Biodivers. Ecol. Res. (The University of Waikato). Hamilton, pp. 71-92.

Howarth, R.W., Schneider, R. \& Swaney, D. (1996): Metabolism and organic carbon fluxes in the tidal freshwater Hudson River. - Estuaries Coasts 19: 848-865.

Junk, W.J., Bayley, P.B. \& Sparks, R.E. (1989): The flood pulse concept in river-floodplain systems. - In Dodge, D.P. (ed.): Proceedings of the International Large River Symposium. Can. Spec. Publ. Fish. Aquat. Sci. 106: 110-127.

Kiffney, P.M., Greene, C.M., Hall, J.E. \& Davies, J.R. (2006): Tributary streams create serial discontinuities in habitat, biological productivity, and diversity in mainstem rivers. Can. J. Fish. Aquat. Sci. 63: 2518-2530.

Lam, C.W.Y. (1981): Ecological studies of phytoplankton in the Waikato River and its catchment. - N. Z. J. Mar. Fresh. 15: 95-103. 
McBride, C., Hamilton, D., Gibbs, M., White, P. \& Stewart, L. (2008): BioFish survey of Lake Taupo, 2006. - CBER Contract Report 68. University of Waikato, Hamilton.

Müller-Solger, A.B., Jassby, A.D. \& Müller-Navarra, D.C. (2002): Nutritional quality of food resources for zooplankton (Daphnia) in a tidal freshwater system (Sacramento-San Joaquin River Delta). - Limnol. Oceanogr. 47: 1468-1476.

Mulholland, W.M. (2010): Box 2.2: History of the lower Waikato Flood Protection Scheme. - In: Collier, K.J., Hamilton, D.P., Vant, W.N. \& Howard-Williams, C. (eds.): The Waters of the Waikato: Ecology of New Zealand's longest river. - Environ. Waikato and Centre Biodivers. Ecol. Res. (The University of Waikato). Hamilton, pp. 16.

Neal, C., Hilton, J., Wade, A.J., Neal, M. \& Wickham, H. (2006): Chlorophyll- $a$ in the rivers of eastern England. Sci. Total Environ. 365: 84-104.

Nilsson, C., Reidy, C.A., Dynesius, M. \& Revenga, C. (2005): Fragmentation and flow regulation of the world's large river systems. - Science 308: 405-408.

O’Neill, B.J. \& Thorp, J.H. (2011): A simple channel complexity metric for analyzing river ecosystem responses. - River Systems 19: 327-335.

Parsons, M. \& Thoms, M.C. (2007): Hierarchical patterns of physical - biological associations in river ecosystems. $-\mathrm{Ge}-$ omorphology 89: 127-146.

Pingram, M.A., Collier, K.J., Hamilton, D.P., Hicks, B.J. \& David, B.O. (2014): Spatial and temporal patterns of carbon flow in a temperate, large river food web. - Hydrobiologia 729: 107-131

Power, M.E. \& Dietrich, W.E. (2002): Food webs in river networks. - Ecol. Res. 17: 451-471.

Rice, S.P., Greenwood, M.T. \& Joyce, C.B. (2001): Tributaries, sediment sources, and the longitudinal organisation of macroinvertebrate fauna along river systems. - Can. J. Fish. Aquat. Sci. 58: 824-840.

Rice, S.P., Fergusson, R.I. \& Hoey, T.B. (2006): Tributary control of physical heterogeneity and biological diversity at river confluences. - Can. J. Fish. Aquat. Sci. 63: 2553-2566.

Rice, S.P., Kiffney, P., Correigh, G. \& Pess, G.R. (2008): The ecological importance of tributaries and confluences. - In: Rice, S.P., Roy, A.G. \& Rhoads, B.L. (eds.): River Confluences, Tributaries and the Fluvial Network. - John Wiley \& Sons Ltd., Chichester, pp. 209-242.

Rosales, J., Blanco-Belmonte, L. \& Bradley, C. (2007): Hydrogeomorphological and ecological interactions in tropical floodplains: The significance of confluence zones in the Orinoco Basin, Venezuela. - In: P.J. Wood, D.M. Hannah \& J.P. Sadler (eds.): Hydroecology and Ecohydrology: Past, present and future. - John Wiley \& Sons Ltd., Chichester, pp. 295-316.
Schiemer, F., Keckeis, H., Reckendorfer, W. \& Winkler, G. (2001): The "inshore retention concept" and its significance for large rivers. - Large Rivers 12: 509-516.

Schiemer, F. \& Hein, T. (2007): The ecological significance of hydraulic retention zones. - In: Wood, P.J., Hannah, D.M. \& Sadler, J.P. (eds.): Hydroecology and Ecohydrology: Past, present and future. - John Wiley \& Sons Ltd., Chichester, pp. 405-420.

Speirs, D.A., Allen, D.G., Kelleher, R.M., Lake, M.D., Marchant, A.N., Mayes, K.A., Watene-Rawiri, E.M. \& Wilson, B.J. (2010): River management. - In: Collier, K.J., Hamilton, D.P., Vant, W.N. \& Howard-Williams, C. (eds.): The Waters of the Waikato: Ecology of New Zealand's longest river. - Environ. Waikato and Centre Biodivers. Ecol. Res. (The University of Waikato). Hamilton, pp. 13-26.

Stanford, J.A. \& Ward, J.V. (2001): Revisting the serial discontinuity concept. - Regul. Rivers: Res. Manage. 17: 303-310.

Thorp, J.H., Thoms, M.C. \& Delong, M.D. (2006): The riverine ecosystem synthesis: Biocomplexity in river networks across space and time. - River Res. Appl. 22: 123-147.

Thorp, J.H., Thoms, M.C. \& Delong, M.D. (2008): The Riverine Ecosystem Synthesis: Towards conceptual cohesiveness in river science. - Elsevier, 208 pp.

Van Kampen, J. (2010): Flow river flow. - Jack Van Kampen, Manukau, 72 pp.

Vannote, R.L., Minshall, G.W., Cummins, K.W., Sedell, J.R. \& Cushing, C.E. (1980): The river continuum concept. - Can. J. Fish. Aquat. Sci. 37: 130-137.

Vant, W.N. (2010): Water quality. - In: Collier, K.J., Hamilton, D.P., Vant, W.N. \& Howard-Williams, C. (eds.): The Waters of the Waikato: Ecology of New Zealand's longest river. Environ. Waikato and Centre Biodivers. Ecol. Res. (The University of Waikato). Hamilton, pp. 93-114.

Varol, M., Gökot, B., Bekleyen, A. \& Şen, B. (2011): Water quality assessment and apportionment of pollution sources of Tigris River (Turkey) using multivariate statistical techniques - a case study. - River Res. Appl. 28: 1428-1438.

Ward, J.V. \& Stanford, J.A. (1983): The serial discontinuity concept of lotic ecosystems. - In: Fontaine, T.D. \& Bartell, S.M. (eds.): Dynamics of lotic ecosystems. - Ann Arbor Scientific Publishers, Ann Arbor, MI, pp. 29-42.

Ward, J.V. (1989): The four-dimensional nature of lotic ecosystems. - J. N. Am. Benthol. Soc. 8: 2-8.

Woodward, G. \& Hildrew, A.G. (2002): Food web structure in riverine landscapes. - Freshwat. Biol. 47: 777-798.

Received 1 February 2013

Modified version received 28 April 2014

Accepted 30 June 2014 